\title{
Multidisciplinarity, Citizen Participation and Geographic Information System, Cross-Cutting Strategies for Sustainable Development in Rural Heritage. The Case Study of Valverde de Burguillos (Spain)
}

\author{
Julia Rey-Pérez ${ }^{1, *(1)}$ and Victoria Domínguez-Ruiz ${ }^{2}$ \\ 1 Instituto Universitario de Arquitectura y Ciencias de la Construcción, Departamento de Historia, \\ Teoría y Composición Arquitectónicas, Escuela Técnica Superior de Arquitectura, Universidad de Sevilla, \\ Av. Reina Mercedes 2, 41012 Seville, Spain \\ 2 Instituto Universitario de Arquitectura y Ciencias de la Construcción, Departamento de Construcciones \\ Arquitectónicas I, Escuela Técnica Superior de Arquitectura, Universidad de Sevilla, Av. Reina Mercedes 2, \\ 41012 Seville, Spain; v_dguez@us.es \\ * Correspondence: jrey1@us.es
}

Received: 21 October 2020; Accepted: 16 November 2020; Published: 18 November 2020

\begin{abstract}
The pace at which cities grow and its impact on heritage management has meant that those heritage assets not linked to the traditionally monumental have been directly doomed to oblivion. The purpose of this article is to present a research methodology backed up by multidisciplinarity and stakeholders' diversity that allows us to highlight the values and singular aspects of this rural heritage. To achieve this, a methodology was devised that is divided into three phases: mapping of human, cultural, and natural resources based on studies undertaken by the Public Sector Administration, experts, and the citizens themselves. The second phase involved the establishment of what to protect amongst all the stakeholders involved. Finally, the third stage entails integration of the information within an urban development framework. In order to work on the development of a diagnosis from three highly different approaches, Geographic Information Systems was used as information management tools, as a means of contrasting it and performing a comprehensive analysis of the same. The development of such a holistic approach provided a patrimonial map of essential resources in the municipality to be taken into account to shape sustainable development strategies inherent to a rural environment of low density. The lack of this comprehensive approach when managing rural heritage in which citizens take on centre stage in decision-making processes unearths two fundamental issues: firstly, the ascertainment of the existence of cultural heritage hitherto abandoned, alongside the need to endow urban governance powers to the public administration, as it falls to them to spearhead this shift in public management.
\end{abstract}

Keywords: historic urban landscape; urban governance; UNESCO heritage; protection; territory; cultural heritage

\section{Introduction}

The 21st century entailed major challenges to contemporary urban planning. The pace of cities' growth and the concentration of the population in therein, to the detriment of rural areas, constitute a phenomenon in which different world organisations have been stressing for some years [1]. Urban development is taking place on a hitherto unseen scale, as expressed by data managed by the United Nations Human Settlements Programme: "Developed countries need to double the amount of urban 
space by 2050 to accommodate the numbers of people forecast, while developing countries will need to expand their urban space by upwards of 300\%" [2] (p. 178). Likewise, over the next 30 years, most urban population growth is expected to occur in cities in developing countries, leading to increasing migration shifts from rural to urban areas [2] (p. 163).

This depopulation phenomenon is placing a series of rural urban areas of major cultural value at risk of desertion on the part of the authorities, thereby affecting their architecture and an intangible cultural heritage engrained in the lifestyles of the community that inhabits them [3]. The designation of heritage protection to monumental elements by the administration has considerably limited the possibilities of expansion of this cultural heritage. This rural heritage is often unprotected, meaning tangible and intangible heritage values are increasingly unknown. The depopulation of municipalities in Spanish inland areas and the consequent deterioration of their cultural and natural resources is increasingly frequent and problematic. This entails the loss of important local knowledge that is really beneficial for the global society, which is in search and in the process of change in terms of food, health, natural contact, and human values [4] (p. 286), [5] (p. 23).

However, the 21st century is viewed as a paradigm shift with regard to the management and consideration of cultural heritage, in the broadest sense of the concept. From within international organisations, the fact that reinforcing knowledge of cultural heritage in areas with low population density can improve local development is highlighted. This occurs in the New Urban Agenda for sustainable development 2030 (2030 Agenda and Sustainable Development Goals (SDGs), approved in 2015 , in which culture and heritage were considered the backbone of sustainable urban development in rural as well as urban areas [6,7]. Later, at the United Nations Conference on Housing and Sustainable Urban Development (Habitat III) [8] held in Quito, the New Urban Agenda was approved, which stresses sustainable management of cultural heritage following an interdisciplinary and participatory approach based on two strategic components: promotion, social participation, and good governance, and territorial and economic development in compliance with sustainable development principles $[9,10]$. All of these concepts are deemed a requirement to ensure an inclusive and holistic recognition of this rural heritage [11,12].

In this sense, considering the fragile situation in which rural heritage currently stands, and taking as a starting point the different contributions of the aforementioned international organisations, this work aims to combine rural heritage and sustainable development. Its aim is, thus, to propose research methodology using multidisciplinary techniques along with stakeholders' diversity that allows us to display the values and attributes of this rural heritage in a certain territory featuring these characteristics. To achieve this, a section devoted to the theoretical framework that reflects on this binomial rural heritage-sustainability is continued. Herein, based on other examples, the key elements are identified to build a heritage research methodology that addresses the rural setting wholly from an integrative perspective. The following section unveils the specific case in which to apply this methodology in order to verify its usefulness and possibilities, namely Valverde de Burguillos, a low-density territory with 14.87 inhabitants per square $\mathrm{km}$ compared to a national average of 91 inhabitants per square $\mathrm{km}$ characterised by a unique rural architecture, by a series of heritage elements linked to its location, namely the "La Cultura del Agua," owing to its hydrological alongside an intangible heritage highly valued by its inhabitants. In the section corresponding to the methodology, the phases that comprise this are outlined: studies undertaken by the public sector administration, experts, and from citizens' perspectives. These are used to work on the development of a diagnosis from three very different approaches. Firstly, Geographic Information Systems have been employed as management tools [13-15]. In the section devoted to findings and discussion, a patrimonial map is drawn up of the essential attributes to take into account the shaping of sustainable development strategies within a rural environment, showing how the development of such a holistic approach can provide the keys to the day-to-day work on strengthening local culture vis-à-vis prevailing globalisation. Finally, the conclusions reveal the chasms and biased interests of the administration when it comes to managing rural heritage in pursuit of sustainable development. 


\section{Theoretical Framework}

In the field of heritage, the 21st century has been accompanied by a significant conceptual change, which has involved a redefinition of the heritage object in pursuit of a holistic consideration of cultural heritage. Likewise, it has shifted from conserving and preserving heritage to using it as a resource for the development of the territory [16]. Another of the substantially renewed spheres has been that of perception and identification, expanding its field of action to the citizens, incorporated as stakeholders in heritagisation. With regard to rural areas, the valuation of its cultural heritage operates in tandem with the heritage-landscape-territory trilogy, which renders the conceptual debate, the identification of attributes, and its own management even more fraught [15]. The complexity of these heritage landscapes increases when the assets that make up said landscape and the protection of nature are also taken into account, meaning their identification and management becomes increasingly more complex, while bolstering the theory of their necessity [17].

Vernacular architecture is a complex social and cultural system, which arises from the human-environment relationship, and which directly reflects ways of living [18] (p. 12). Due to its connection to the place, the diversity of this heritage is so widespread that it is not possible to establish typologies or chronological progression. The uniqueness of this architecture is such that each case is unique and unrepeatable. It is an architecture that reveals the serenity, humanity, and intelligence of these settlements, as defined by Rudofsky [19]. It features an extensive typological and functional range that is extraordinarily wide and rich, with multiple variants at community, county, and even local levels [20] (p. 14). However, as expressed by Maldonado and Vela, compared to other types of architectures that display evolution in accordance with the economic, technological, and cultural changes of urban life, these rural architectures are halted at the cultural moment in which they were devised [21] (p. 1).

In the light of international concern regarding the pace of cities' growth and the concentration of the population therein [2], in the case of rural landscapes and vernacular heritage, the very opposite occurs. This type of heritage is condemned to oblivion, as it does not share the values close to monumentality traditionally taken into account by heritage protection bodies [22]. Abandoned and overlooked, this endangered architecture provides the keys nowadays to work on local identity in the face of prevailing globalisation [18]. However, they are extremely vulnerable and face serious issues involving obsolescence [23]. Likewise, the lack of appreciation and awareness towards this architecture has contributed to the devaluation of the rural environment, the lack of sensitivity towards upkeep of heritage on the part of the citizens, which has facilitated looting, vandalism, and urban speculation. Lastly, the failure to enhance this architecture has led to a shortfall in studies, measures, and regulations, as well as the development of inappropriate intervention criteria [20] (pp. 23-25).

Nonetheless, faced with being considered at risk, and according to international guidelines, this heritage has been unearthed as an opportunity, since heritage itself is a generator of identity, the basis for individual growth and collective memory, as well as being decisive in terms of quality of life, the provision of stability and social cohesion, while enhancing resilience and creativity [24]. Indeed, the guidelines set forth by international organisations such as the 11th Conference on Rural Development in 2018 [25] and the 12th Conference in Seoul in 2019 of the Organization for Economic Co-operation and Development (OECD), place in their documents the social, economic, and environmental well-being and the quality of life of residents in unpopulated rural areas (access to services, basic needs covered, future prospects) as one of the priorities to measure the success of development [26]. In this sense, and taking these considerations as a starting point, the incorporation of heritage as the fourth pillar of sustainable development is more than evident [27-29]. Depending on how this heritage is part of sustainable development strategies, it acts as an indicator of how the past is being acknowledged in current development strategies and what bearing this will have on the future. Sustainable development is being backed that balances past-present and future outlooks [30].

For the incorporation of rural heritage into development strategies, an approach is necessary that allows incorporating the maximum available information on a good and from the most varied 
perceptions, meaning that its valorisation should be as wide ranging as possible. Today, valorisation cannot be limited to historical and identity, immaterial and symbolic and scientific value as indicated in institutional approaches [15] (p. 30), but must be committed to all the stakeholders involved in its development and enhance its collective dimension through widespread heritage values and attributes. The Recommendation on the Historic Urban Landscape (HUL) and its six steps for its implementation (Table 1) was born with this purpose, to facilitate the integration of cultural heritage and urban development, with special emphasis not only on the participation of the different disciplines, but also in the role of other stakeholders and citizens themselves in heritage management [31]. This approach encourages the development of a democratic model of urban governance that is for everyone and must involve everyone [32] (pp. 26-30). There is no doubt that the incorporation of other stakeholders, alongside the administration, in the consideration of heritage will provide new information, much broader and more inclusive, which consequently will generate sustainable development strategies very different from those developed up to the present. This model has prompted several local governments to develop urban strategies based on cultural heritage $[33,34]$ and incorporating citizen perception, resulting in the development of local communities and the fulfilment of human needs. From within UNESCO, an invitation is extended to local governments to use this holistic approach, both in urban as well as rural settings [35-39].

Table 1. The six steps for the implementation of the Recommendation on the Historic Urban Landscape (HUL).

\begin{tabular}{c}
\hline Historic Urban Landscape Approach. Six Steps. \\
Mapping of natural, cultural, and human resources \\
Consensus among those involved in what to protect (values and attributes) \\
Assessment of vulnerability to change and development \\
Integration of the information generated in an urban development framework \\
Prioritisation of actions for conservation and development \\
Establishment of local partners and management frameworks
\end{tabular}

Likewise, the management of information on such a scale conditions the integration of new knowledge-based technologies into heritage research and in the dissemination of results. Thus, new readings can be obtained, while collecting and working the information in a more efficient and innovative way, and that is where the Geographic Information Systems tool [40] (p. 63) comes into its own. New technological advances have contributed to the fact that research methodologies based on bibliographic consultation, as well as on maps and cartography, official archives, etc., are evolving towards a more streamlined system based on computer advances and data availability. This progression allows us to delve into the different dimensions of the information, establishing, for example, relationships or patterns that would otherwise be very difficult to identify [13,41,42].

This diversity and complexity of relationships and conformation processes, along with the variety of participant stakeholders, are those who highlight the need for new research methodologies into these heritage landscapes that allow for the development of a truly innovative and sustainable management. This would mean that all the singularities of its values and patrimonial attributes are collected, while all the affected stakeholders' views are taken into account. A critical appraisal of the instruments used in traditional institutional asset recognition is necessary. An inclusive approach to heritage must be based on a comprehensive knowledge of this complex heritage, taking into account all its singularities and with a broad perspective on what should be protected and what the criteria are for its intervention. In short, a new positioning of how to manage this complex heritage, understanding the most suitable instruments to achieve this. The incorporation of the different stakeholders in their identification is what contributes to the process a sustainable approach.

The combination of recent knowledge technologies with this new heritage vision generated by the HUL approach implemented in Valverde de Burguillos, aims to identify inclusive sustainable development strategies based on the heritage assessment developed by all stakeholders and the rest of 
the disciplines involved, along with input from management. The enhancement of local resources by reactivating them in rural territories, with the support of scientific and technological knowledge, is the only way to give a voice to this heritage at risk, while developing sustainable rural development strategies according to citizenship and the cultural values identified.

\section{Case Study: Valverde de Burguillos}

Located $96 \mathrm{~km}$ from Badajoz to the southwest, the municipality of Valverde de Burguillos features an area of $19 \mathrm{~km}^{2}$ and a population of 273 inhabitants [43]. It belongs to the Zafra-Río Bodión region and to the Fregenal de la Sierra judicial district. The loss of population, on the one hand, which shifts from Valverde de Burguillos to larger urban centres offering greater opportunities, and the negative vegetative balance, on the other, has caused a situation of rural depopulation, such as that which affects almost the entire Autonomous Community of Extremadura [44], in particular the province of Badajoz (Figure 1). This rural depopulation strongly affects the municipality of Valverde de Burguillos, which reached its maximum number of inhabitants between 1930 and 1950 and is currently at its lowest ebb, as well as withstanding a negative demographic trend, having already reversed its population pyramid [45] (p. 214). The municipality of Valverde de Burguillos unveils a landscape of holm oaks, cereal crops, and small orchards or homesteads. The dominant landscape is that of undulating terrain covered in most cases by low-coverage meadows-the main ecosystem of the region, characterized by the presence of holm oaks and cork oaks-with low elevations and by the banks excavated by the Bodión River, the "Riberita de los Frailes" and the Najarrillo stream [46] (pp. 45-46). The municipality is renowned for having a large number of springs. The presence of the large number of springs is due to the upwelling of groundwater caused by fractures in the materials. The use of water is part of the region's Islamic legacy, which led to the flourishing of family-type orchards, almost entirely attached to these springs and which constituted a key element of the livelihood of the people of Valverde, who were renowned locally for their itinerant sale of these homegrown products [46]. Currently, $90 \%$ of these orchards or vegetable gardens are in disuse [47].

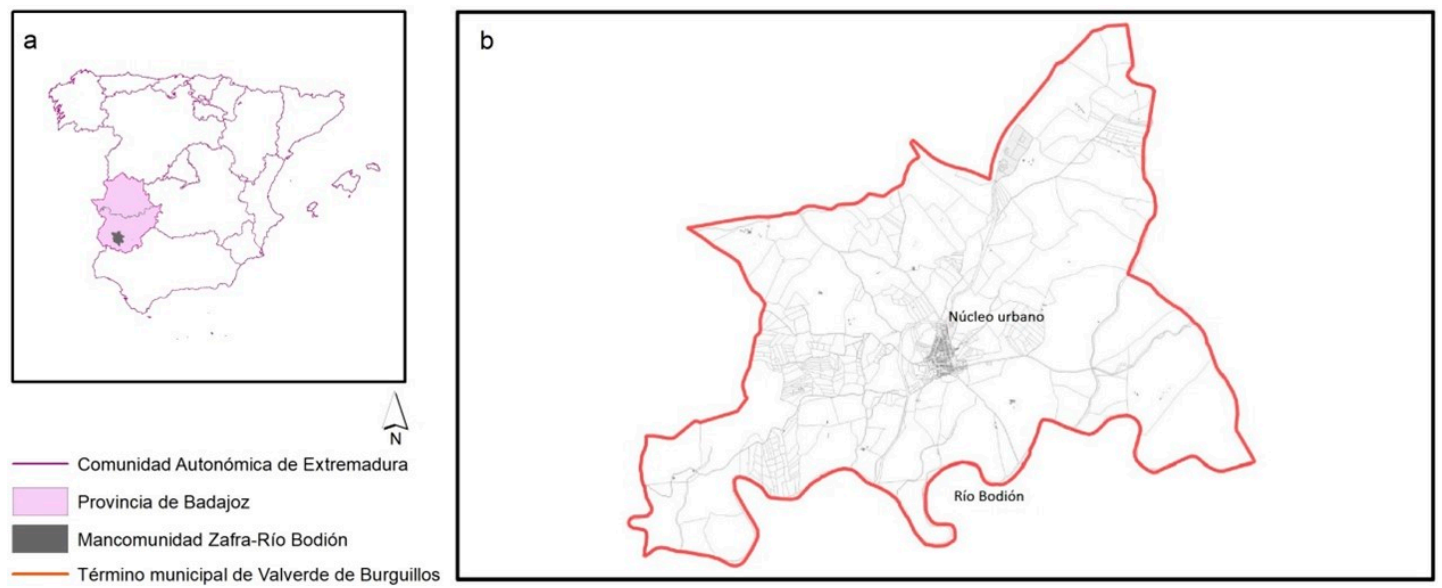

Figure 1. (a): Location map with autonomous community, province, and commonwealth (Legend: Comunidad Autónomica de Extremadura (Autonomous Community of Extremadura), Provincia de Badajoz (Badajoz Province), Mancomunidad Zafra-Río Bodión (Zafra-River Bodión commonwealth) and Término municipal de Valverde de Burguillos (Municipal boundary of Valverde de Burguillos). (b): Municipal boundary of Valverde de Burguillos, with Bodion River (Río Bodión) coinciding with the southern limit, and urban centre (Núcleo urbano). Prepared by the TUTSOSMOD working team from the following sources of information [48,49].

Likewise, Valverde has assets protected under the declaration as a BIC ("Site of Cultural Interest") of "La Cultura del Agua" composed of fountains, pillars, pools, a mill, a hydraulic pipeline, and a unique electro-flour factory, with the dam and the path that leads towards it. Moreover, a Chalcolithic 
fortified site in its territory and, around the Bodión River, the anthropised footprint of agro-ecosystems, the riparian woodland, and the built landscape of the pasturelands. In the urban environment, it has the Church of Our Lady of the Antigua (16th century), the Hermitage of Our Lady of the Valle, and a hamlet with typological interest, with certain traditional construction solutions that have not completely disappeared. The town displays the characteristic rural architecture of the Extremadura region, built using brickwork with a lime paintwork coating. It also preserves interesting idiosyncrasies of this architectural style, such as the cladding with brown or black lime and certain constructive elements inside the buildings, such as the vaults or cobbled paving for the passage of animals. With regard to intangible heritage it preserves well-preserved religious, cultural, and gastronomic rites. Valverde's cultural heritage has multiple dimensions and is closely linked to people and lifestyles, highlighting the important bond that people's knowledge and collective wisdom have with the properties that typify it. This situation demands the protection of these elements, since their safeguarding would establish measures for their continuity and a series of strategies linked to the enhancement of this type of property.

Despite the diverse attributes and heritage values that are on view in Valverde, ranging from the intangible to the architectural, passing through the landscape, on a legislative level, this municipality is detained, its administrative protection being limited to the cataloguing of the aforementioned church, the hermitage, and, to a lesser degree, seven houses in the urban nucleus, on the one hand, and, on the other, the dossier on "La Cultura del Agua" on the occasion of its declaration of Asset of Cultural Interest in the category of Site of Ethnologic Interest [50]. Even so, this declaration is a significant step, since, although the protection is limited to architectural or archaeological elements, the value of the territory is mentioned, incorporating heritage attributes linked to the landscape, visuals, gastronomy, trading, traditions, and social relationships (Figure 2). For this reason, our study shall be focused on these aspects. In short, we are facing a set of elements that are scattered amongst the territory and the urban complex and related to the traditional uses of agro-ecosystems, pursuant to Law 2/1999, on the Historical and Cultural Heritage of Extremadura, in its Title IV [51]. In this sense, the aforementioned approach is considered necessary to make a comprehensive approach to said rural heritage and use the heritage elements identified strategically to define possible future interventions in a sustainable development strategy.

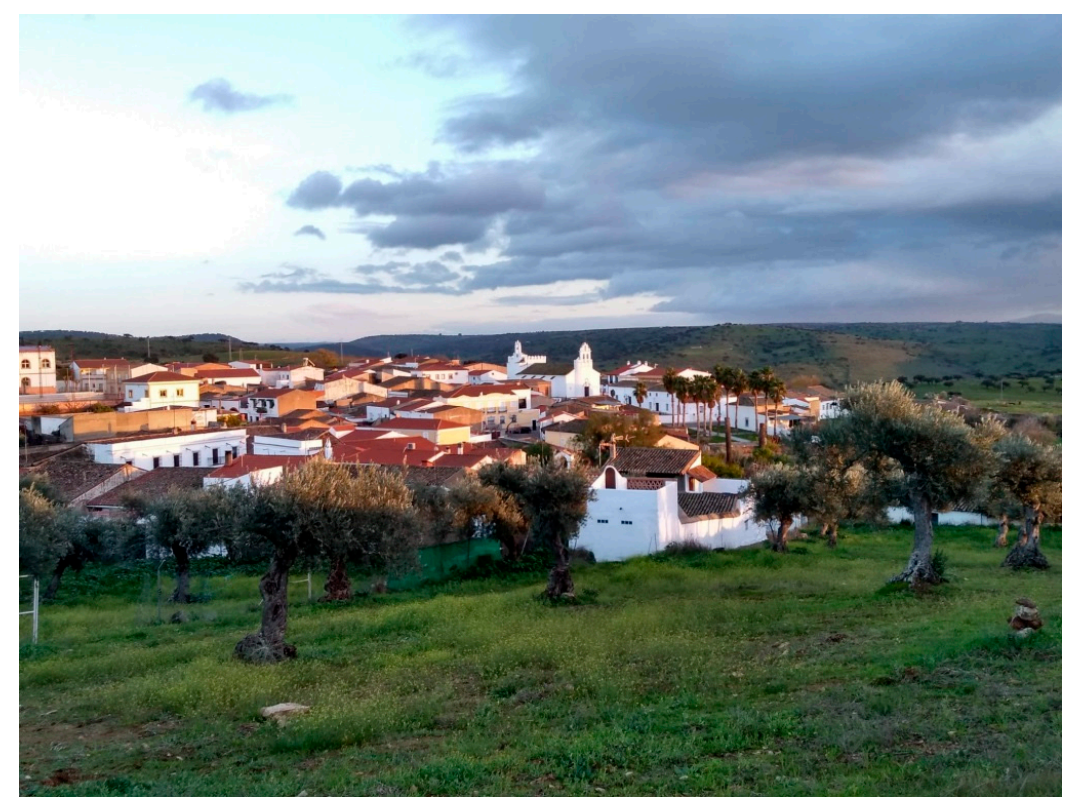

Figure 2. Overview of Valverde de Burguillos. Author: José Antonio Domínguez Jara. 


\section{Methodology}

This methodology seeks to incorporate into the heritage field those rural landscapes that are solely valued from the local scale, close to the individual and their field of experience and not necessarily valued by supralocal institutions. One of the main features of this methodology is that it is an inclusive and integrating process, and that it goes beyond a biased approach, for that reason, the three stakeholders that will provide the necessary information to compose the database are: the administration in charge of managing and protecting the property, the stakeholders of the scientific-technical sector (academia and experts) along with the general public. This inclusive, holistic, and integrative approach takes as a reference the six steps proposed by the HUL for its implementation [31,52]. However, this Action Plan serves as a guideline and must be adapted to the political, economic, and contextual conditions of each case, thus, it is not being deemed necessary to respect the order of the steps proposed. Owing to the conditions and aims of this research, the amplitude of the heritage resources requiring consideration has been particularly noteworthy for the proposal of the methodology of the case under study (step 1). Similarly, the need to incorporate the actual citizens into the decision-making process (step 2) and the addition of this information to an urban development strategy are significant. The aim was to propose a highly clear and concise methodological process aimed at identifying the heritage resources, hence, neither the definition of vulnerability (step 3), nor the prioritisation of actions (step 5) nor the identification of partners (step 6) has been tackled, as these would form part of another phase of the research. The phases of the methodology are the following:

1. MAPPING RESOURCES. Identification of human, cultural, and natural resources. The consideration of the patrimonial element beyond the object to identify patrimonial values of a different nature (landscape, economic, social, environmental ... ). The vision provided by the local administration, from the academy and from citizen participation is considered of the utmost importance. To achieve this, it has been necessary to determine which sources of information the different stakeholders provide and to trace these thoroughly (Table 2).

2. REACHING A CONSENSUS on what to protect. To develop this phase, a collaborative mapping strategy is used, which implies working in tandem with all the stakeholders involved.

3. INTEGRATION OF INFORMATION INTO THE URBAN DEVELOPMENT FRAMEWORK. Drawing up of a heritage map of the heritage resources of the municipality based on the information provided by the different stakeholders. Said document has been made available to the Administration.

For the development of this methodology, the cartographic tool is considered essential throughout the entire process, since to be able to cross the information collected, relate it and be able to contrast it, it is necessary to collect the existing heterogeneous information in a single digital document and submit it to an integrated analysis. That chosen software is ArcGIS version 10.4.1 manufactured by ESRI(C). The following stages have taken place in the graphic process:

- Creation of a georeferenced database for alphanumeric and graphic information input. Given the heterogeneous nature not only in the data format, but also in its subject matter, the interdisciplinary meetings between researchers, technicians, citizens, and the administration to gather data and contrast information are noteworthy. Furthermore, numerous field visits have been carried out in Valverde de Burguillos, including stays of varying duration. A preliminary task has been undertaken prior to devising the information fields consisting of the definition of a series of attributes (columns of the data tables) in accordance with the subsequent analysis to be performed.

- Management of spatial and thematic information. Integration, consultation, and interpretation of the data on a digital cartographic base built for Valverde de Burguillos aimed at generating valid conclusions for the study.

- Analytical functions. Handling of information on a Geographic Information System (GIS) basis, data crossing, and generation of new information and points of view on the layers that comprise 
the project. Amongst these graphic analysis functions we find: vectorisation of the agricultural territorial information from the SIGPAC viewer (surfaces of ecological interest, landscape elements, cartography, places of regional interest (LIC)). Coupled with the foregoing is the analysis of visual basins using the Digital Surface Model at $5 \mathrm{~m}$ from the 2018 LIDAR flight; the comparative analysis of disperse edifications using topographical maps from 1945 to 2019. Lastly, the digitisation of citizen created maps, overlapped with vectorial layers from cartographic severs.

- Representation and output of information. Characterisation of the ethnographic heritage, symbolisation and justified identification of the heritage elements. In this stage, care has been taken to ensure that the notification of information has been synthetic and clear. For this reason, the maps had to contain a simple symbology and express few yet potent ideas (for example, the map of significant heritage elements for the citizens, though those not contemplated by the administration). It became evident to create tables broken down into elements with a more user-friendly graphic format than the internal GIS tables. Therein, the information fields must be combined (which include positive and negative appraisals of each element, aside from the basic information) with illustrative images to assist comprehension.

Table 2. Sources of information provided by the stakeholders involved.

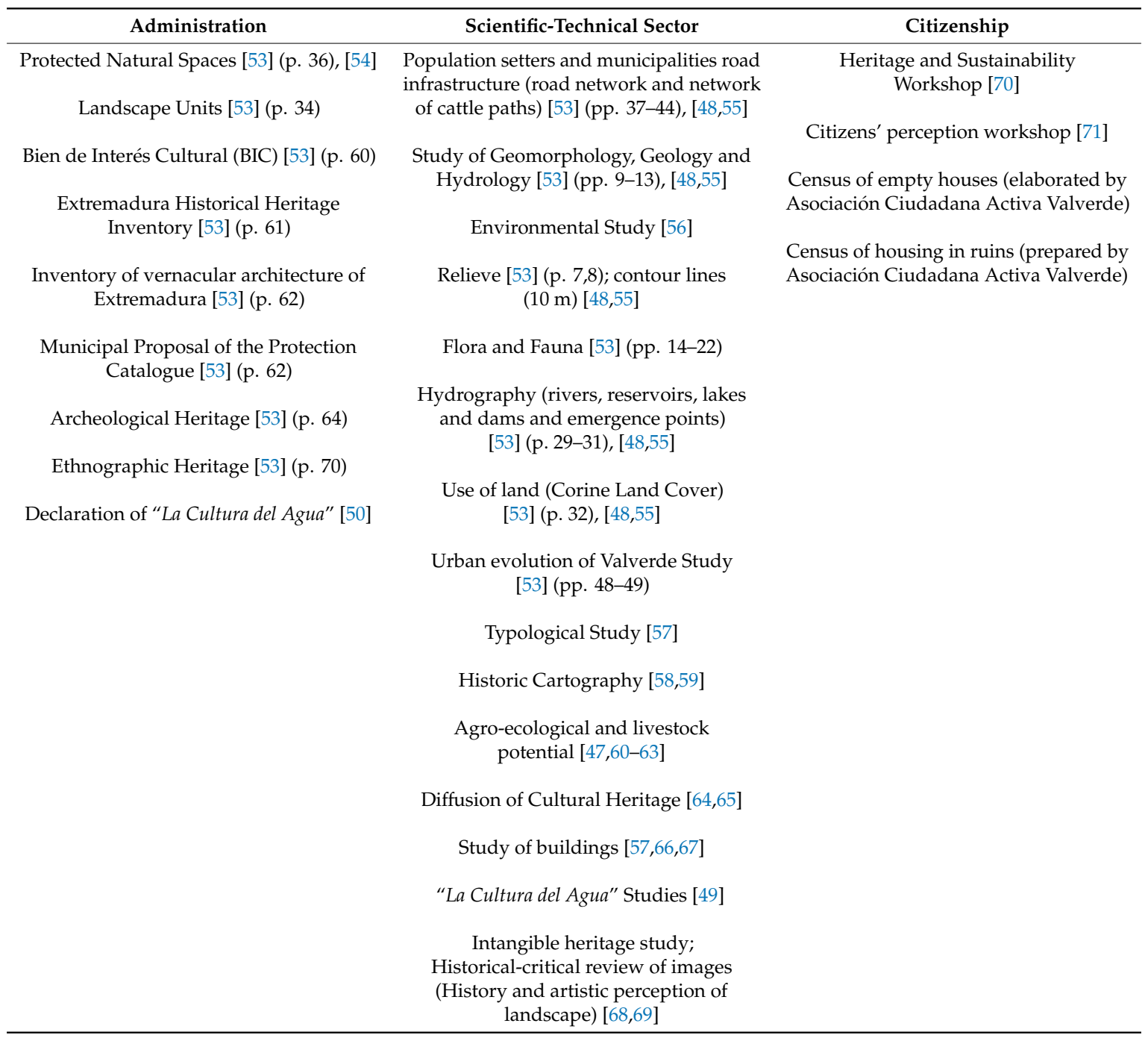




\section{Findings}

Next, the results of each of the phases of the methodology mentioned are developed.

\subsection{Phase 1: Mapping of Natural, Cultural, and Human Resources}

As indicated in Table 2, with the first step of the HUL what is being sought is not to limit the knowledge and management of cultural heritage to the vision defined by the legislative bodies and to expand the heritage knowledge with the information provided by academia and the citizenship.

\subsubsection{Assets Protected from within the Public Sector Administration}

The information generated from administrative bodies at heritage level is limited to the declaration of Site of Cultural Interest (hereinafter, BIC) in the name of "La Cultura del Agua" in Valverde de Burguillos, Badajoz, in the category of Asset of Ethnological Interest [50] and the elements of the Protection Catalogue [53] (p. 62). Both documents have brought to light the heritage, tangible and intangible, that exists in the municipality and puts the focus of attention on the transformations that are affecting these assets, urging their protection and enhancement.

In the case of "La Cultura del Agua" dossier, this consists of a group comprised of ten cultural assets, located within the urban area of the population and in its immediate rural environment. This architecture displays a close bond with the territory, with the crops, with its hydrography, and with other communication infrastructures, such as roads, sidewalks, etc. The following ten elements have been considered: 1. "El Pilar" drinking fountain; 2 "El Charco" laundry fountain; 3. Cistern "Fuente Nueva"; 4. "La Presa (Dam)," and the pedestrian path over the old canal that leads to the "San Luis" Electrically powered flourmill; 5. "El Pocito" watering fountain; 6. "La Reina" laundry fountain; 7. Pond number $1 ; 8$. Pond number 2; 9. Najarrillo mill; 10 . "San Luis" electrically powered flourmill. In the report that accompanies the dossier, "these elements of dispersed architecture related to the traditional uses of our agroecosystems ( . . ) are described as previously forgotten testimonies, which have fallen into a ruinous state of disregard and disappeared, before being properly studied and recorded, as a consequence of the abandonment of country life, and the disappearance of traditional agriculture" [51].

Elements that must not be taken individually, but rather are part of a system that has enabled the functioning and development of the society that has inhabited it. The existing water resources have provided the municipality with a public system of sources, ditches, canalisations, and miscellaneous flour production points that have characterised the socioeconomic profile of the population for centuries. Alongside their material and architectural qualities, they are also significant elements in the socialisation of the population, since they have major symbolic value that must be preserved and protected due to their legacy, under the most optimum conditions, to future generations [72,73].

However, although instigation represents progress in its processes in terms of conservation, protection, and also in its institutional recognition, no tangible measures have been carried out to initiate its safeguarding. Furthermore, the report does not analyse its elements in depth, limiting itself to a brief description of each object that does not contemplate its territorial dimension or its interaction with the landscape. A more deep-rooted analysis of "La Cultura del Agua" is required, which documents, characterises, and locates all the elements, always contextualised, contributing to its valorisation, preservation, and facilitating possible future interventions. The state of neglect and ruin of the elements is considerable, requiring the undertaking of urgent actions to prevent their disappearance. More recently, the Valverde de Burguillos City Council requested the inclusion of the "San Luis" electrically powered flourmill, the dam, and the path that leads to it (Figure 3). Likewise, Law 2/1999, passed on March 29, on the Historical and Cultural Heritage of Extremadura, establishes which elements are declared Inventoried Assets and a certain type of protection are provided for their conservation from a gradient from higher to lower protection. COMPREHENSIVE PROTECTION (Grade I and Grade II) for elements of a monumental or singular nature, such as the Church of Our Lady of Antigua (16th century) or the Hermitage of Our Lady of the Valle, amongst others. Along with PARTIAL 
PROTECTION; assets with architectural and typological value, which do not reach the previous degree, yet which must be protected ensuring their maintenance and conservation, and preservation of their identity, and ENVIRONMENTAL PROTECTION, distinguishing between Category I (typological, compositional, or decorative elements considered of interest for facades, roofs, and elements visible to the outside) and Category II (free spaces and squares of historical interest). In this case, the most significant examples of residential complexes stand out.
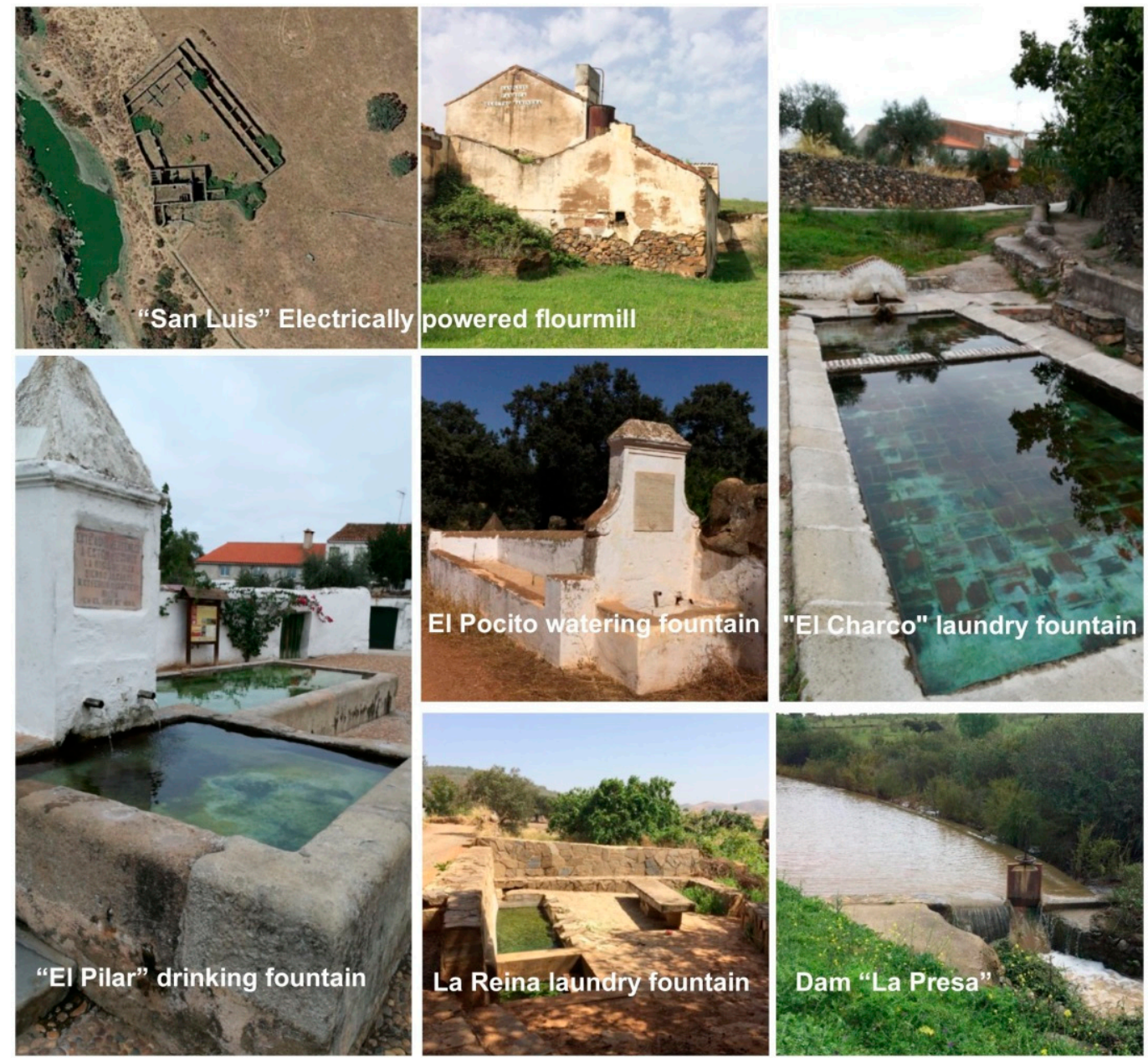

Figure 3. Selection of "La Cultura del Agua" elements declared Sites of Cultural Interest (BIC). Prepared by the TUTSOSMOD working team from the aforementioned sources of information: maps 1-3 [58]; images a-e [49].

The Advancement of the Municipal General Planning Action includes these inventoried assets and also develops a list of proposed assets for inclusion in the Catalogue of Protected Assets. Amongst them are those already described as "La Cultura del Agua", yet, furthermore, other elements are detected that are worth mentioning and must be taken into account for the relational analysis with other elements of heritage value. Figure 4 shows elements of the Catalogue of Inventoried Assets and that are proposed for inclusion in the Catalogue of Protected Assets. It is worthwhile stressing that the municipal corporation is an active agent in a matter as important as the emotional enjoyment of the collective heritage, waiving its local resources in favour of leisure and sports (visits, cultural agenda, canoes), gastronomy, or preservation of miscellaneous landmarks and festivities. 


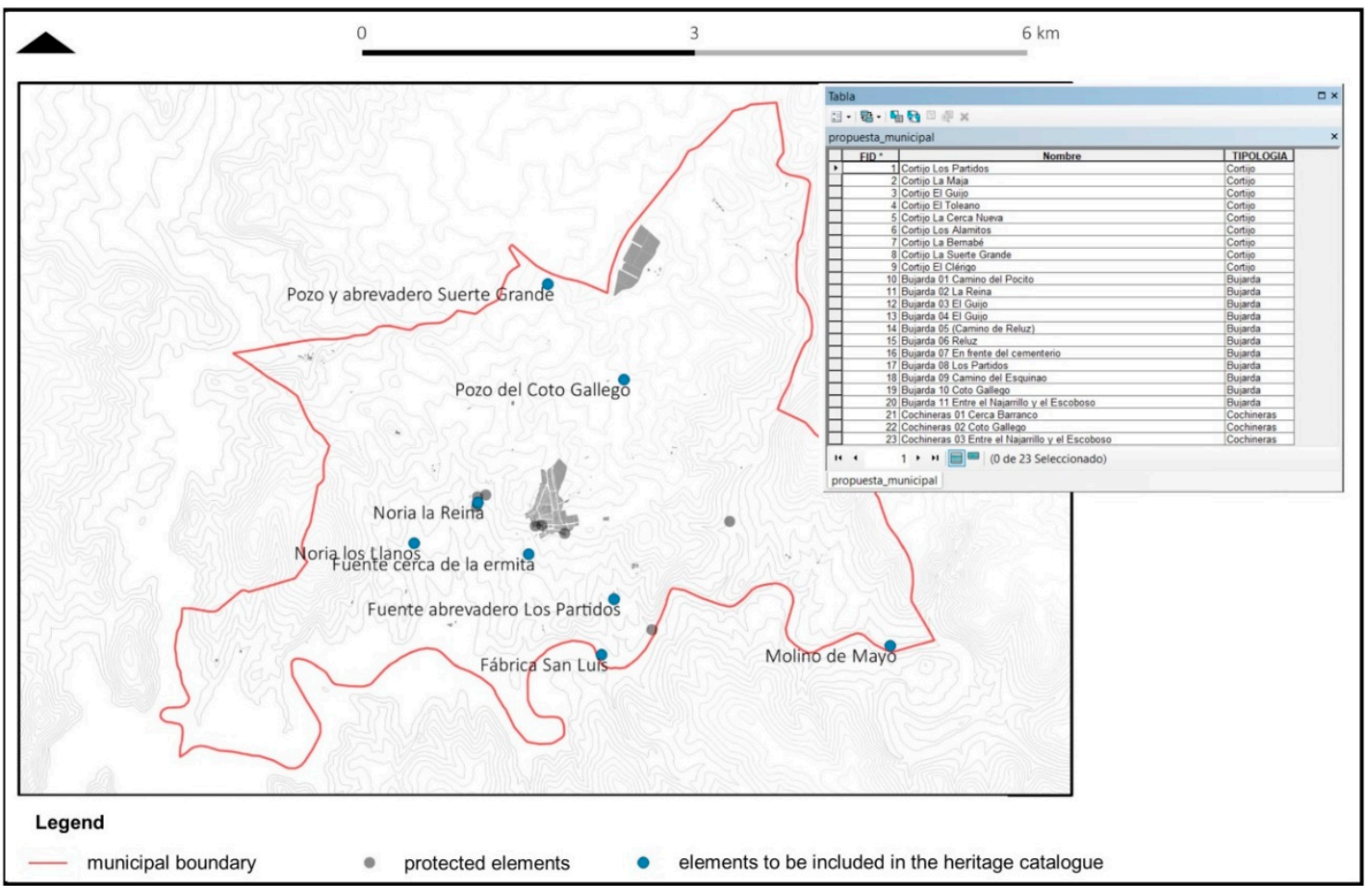

Figure 4. Construction of the geo-database of heritage elements related to "La Cultura del Agua". Prepared by the TUTSOSMOD working team and Irene Carnicero Valero.

\subsubsection{The Contribution of Academic and Research Works}

This work is aligned with several papers focused on issues of agro-ecology, ecological anthropology, and rural development in the commonwealth with the aim of expanding knowledge and revaluing the resources of the place. On the subject of built heritage and vernacular architecture in Valverde de Burguillos, during the most recent academic years the opportunity to participate either in guidance or in carrying out academic work on Valverde de Burguillos has also arisen. In this way, the urban and constructive characterisation of the traditional farmhouse in the core of the municipality has been deepened [57,67]; the location and function of livestock pathways and the types of soil have been analysed; the relationship between hydrography and "La Cultura del Agua" has been investigated [49]; BIM, GIS, and ICT information models have been tested for wealth management $[65,66]$; and they have reflected on the immaterial values associated with the collective memory of this place [68]. Through these approaches, several phases of the process have been covered: understanding the problem, contact with the local reality, field work, systematisation of the data collected, information management, consultation with local technicians, and production of complex graphical information of utility.

Likewise, the studies developed from geomorphology, geology, and hydrology, as well as environmental studies show how the natural heritage of Valverde identifies the pasture, the river ecosystem, its flora and fauna as the defining resources of the natural landscape, which is also linked to the knowledge related to the traditional forms of rural life in this geographical area. The loss of biodiversity in terms of flora and fauna and the extinction of certain native plant species are also evident. The proposal contemplates the cooperative work between professors of different disciplines and students of the University of Seville, many of them Extremadura natives, in order to reach a broader viewpoint regarding the issue raised. 


\subsubsection{Citizens' Perception}

To integrate citizens into the decision-making process, the II Workshop on vernacular initiatives is underway in Valverde de Burguillos. Citizen perception through collaborative cartographies, with the aim of identifying those heritage elements that distinguish Valverde de Burguillos. As a conceptual strategy, and in order not to influence citizen decision-making, at no time was the word "heritage" mentioned, in order to obtain the desired information. This workshop's aim is to ascertain what is the perception that citizens possess of their urban complex, of their public spaces, of the different areas, of their patrimonial values, and also their general outlook on the issues to be considered for the revaluation and conservation of the cultural and natural heritage of Valverde. The main idea was to obtain information to move from multidisciplinary technical planning to comprehensive participatory planning [74,75].

The approach to the city's stakeholders was developed through three activities, performed individually and in groups, in which mainly visual techniques were used so that each group could present their true picture of their viewpoints, while combining them with idea exchange dynamics:

1. The first activity was developed individually in which each of the participants was provided with a card, where from the five senses they had to reflect those identity elements of Valverde, the causes, and suggestions to improve it. The proposal was made to tackle the phrase: "We would take from Valverde ... because ..."

2. Activity 2 consisted of the same card, but where they had to identify those anomalous elements. We focused on the phrase: "It is not possible that ... it will continue to occur in the next 100 years because..."

3. Activity 3, conducted in 3 groups of 12 people, consisted of identifying, among all, those elements of their area with a special value, and for this they were provided with planimetry and colours to locate them on the plans, both on a territorial and urban level. They were proposed to work with the phrase: " ... it is an element (that should be) valued as historical heritage because ... Its state of conservation is ... because ...".

Amongst the main results of exercise 1, the general landscape stands out, where nature and the environment come to the fore, as well as the issue of visuals from the town to the territory, and the urban component. Issues such as gastronomy (slaughter, bread-making, sweets, asparagus ... ), the sounds of birds, the smell of the countryside or wet earth or the personality of the Valverde people are other leading elements that give clues about the peculiarities and singularities of the heritage from this place, hitherto unrecognised (Figure 5, Tables 3 and 4). However, exercise 2 concentrates its answers on the concern of the inhabitants in relation to empty and deteriorated houses, the state of the church, the loss of gastronomy, the deterioration of nature, the increase in heat or loss of the traditional trades, mentioning in lesser incidence the non-integrated architecture, the scarce accessibility, the dirt, the absence of children, and the systematic abandonment of Valverde, which accentuates the perception of loneliness on the part of the elderly (Table 5). Finally, it is in activity 3 that the perception of the territory, and the relationship of its morphology with the cultural heritage of Valverde, comes to the fore. The importance of crops begins to be related to the gastronomy of the place, which affects certain buildings and certain festive rituals (Figure 6). 
Exercise 1 (appreciated elements)
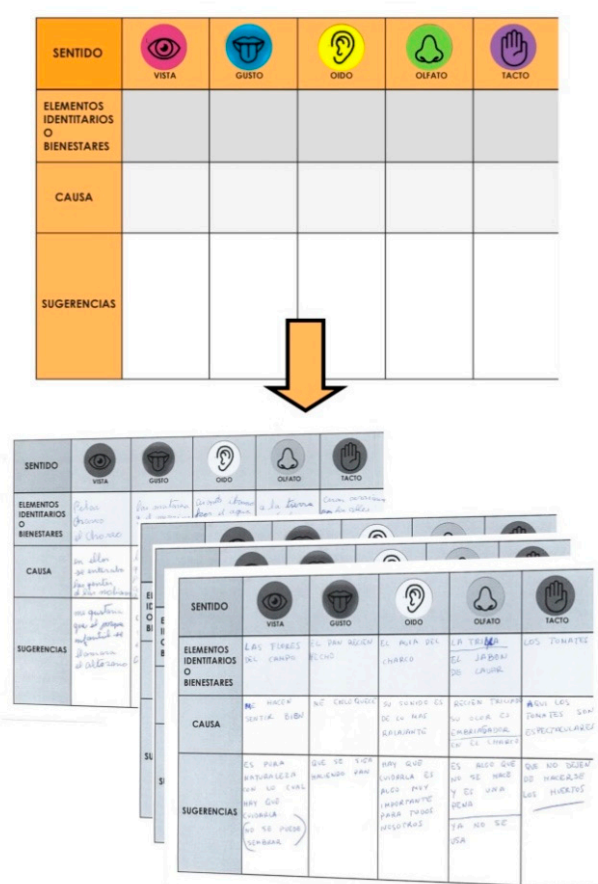

Exercise 2 (anomalous elements)
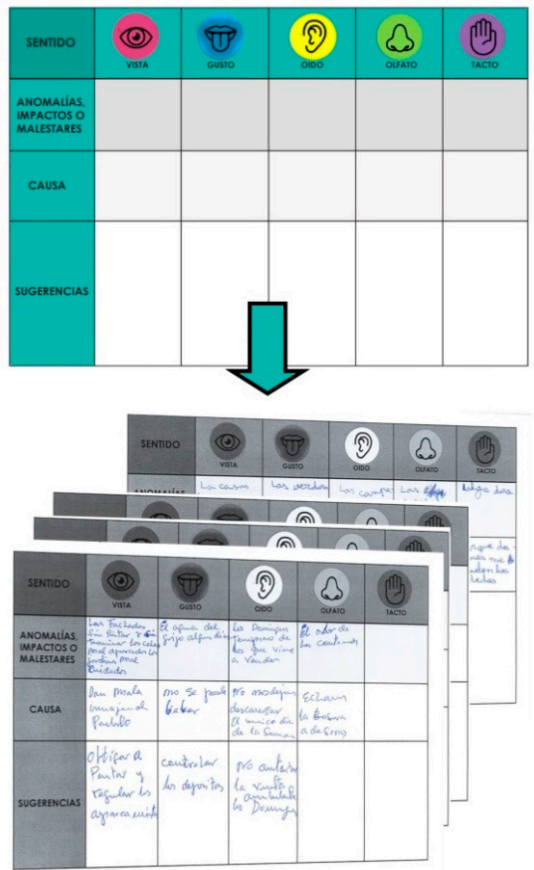

Figure 5. Worksheet for exercise 1 and 2, identity and anomalous elements of Valverde through the senses. Authorship: TUTSOMOD work team.

Table 3. Content of one of the worksheets for exercise 1.

\begin{tabular}{|c|c|c|c|c|c|}
\hline SENSE & SIGHT & TASTE & HEARING & SMELL & TOUCH \\
\hline $\begin{array}{l}\text { IDENTITY OR } \\
\text { WELLBEING } \\
\text { ELEMENTS }\end{array}$ & $\begin{array}{l}\text { [hw] Flowers in } \\
\text { the country }\end{array}$ & $\begin{array}{l}\text { [hw] Freshly } \\
\text { made bread }\end{array}$ & $\begin{array}{l}\text { [hw] Water in } \\
\text { the pond }\end{array}$ & $\begin{array}{l}\text { [hw] The threshing } \\
\text { Soap for washing }\end{array}$ & [hw] Tomatoes \\
\hline CAUSE & $\begin{array}{l}\text { [hw] They make } \\
\text { me feel good }\end{array}$ & $\begin{array}{l}\text { [hw] It drives } \\
\text { me wild }\end{array}$ & $\begin{array}{l}\text { [hw] Its sound } \\
\text { is really } \\
\text { relaxing }\end{array}$ & $\begin{array}{l}\text { [hw] Freshly } \\
\text { grounded. Its smell } \\
\text { is intoxicating in } \\
\text { the pond }\end{array}$ & $\begin{array}{l}{[\mathrm{hw}] \text { The }} \\
\text { tomatoes here are } \\
\text { second to none }\end{array}$ \\
\hline SUGGESTIONS & $\begin{array}{l}\text { [hw] It is nature } \\
\text { in its purest state, } \\
\text { so we have to } \\
\text { look after it (they } \\
\text { can't be planted) }\end{array}$ & $\begin{array}{l}\text { [hw] That they } \\
\text { continue to } \\
\text { make bread }\end{array}$ & $\begin{array}{l}\text { [hw] We have } \\
\text { to look after it } \\
\text { as it is } \\
\text { somewhat } \\
\text { important for } \\
\text { all of us }\end{array}$ & $\begin{array}{l}\text { [hw] It's no longer } \\
\text { done and that is a } \\
\text { shame. Not used } \\
\text { any more }\end{array}$ & $\begin{array}{l}\text { [hw] That the } \\
\text { orchards and } \\
\text { vegetable } \\
\text { gardens remain } \\
\text { in use. }\end{array}$ \\
\hline
\end{tabular}


Table 4. Activity 1 results. Identity elements from the five senses. Number of times mentioned.

\begin{tabular}{|c|c|c|c|c|c|c|c|c|c|}
\hline SIGHT & No. & TASTE & No. & HEARING & No. & SMELL & No. & TOUCH & No. \\
\hline Highlands of "El Guijo" country state & 10 & Albéchiga (a local variety of Prunus persica) & 30 & Clock bells & 50 & Trees & 20 & Water & 20 \\
\hline Trees & 10 & Charcoal-grilled (traditional dish) & 10 & Ancient carnivals & 20 & Fire (home candle) & 40 & Animals & 20 \\
\hline Popular architecture & 10 & Cooked frogs (traditional dish) & 40 & Conversation friends & 10 & Mowed grass & 20 & Wall lime & 10 \\
\hline Streets & 30 & Prunus spinosa & 10 & Valverde choir & 10 & Cake & 30 & Climate & 10 \\
\hline Painted facades traditional & 10 & Caldereta (traditional dish) & 10 & "El Charco" laundry fountain & 10 & Flowers of the field & 70 & Education people & 10 \\
\hline Attic & 10 & Camuesa (apple local variety) & 10 & Town fountains & 30 & Gastronomy & 100 & Quercus ilex & 10 \\
\hline "El Charco" laundry fountain & 20 & Pork meat & 20 & "La Presa" (Dam) & 40 & Washing soap (threshing) & 10 & Asparagus & 20 \\
\hline "El Chorro" laundry fountain & 10 & Coriander & 10 & Rain & 20 & Rain & 10 & Family & 20 \\
\hline "El Pilar" drinking fountain & 20 & Piglet & 10 & Nature & 30 & Traditional pig slaughtering & 20 & Flowers of the field & 50 \\
\hline Hermitage of Our Lady of the Valley & 20 & Dessert competition & 10 & Birds & 170 & Orange trees in the street & 10 & Orchards & 10 \\
\hline Flowers of the field & 20 & Cakes & 40 & Bodión river & 10 & Nature & 30 & Traditional games & 30 \\
\hline Town fountains & 10 & Hermitage & 10 & Peace of mind & 10 & Bread & 40 & Pots & 10 \\
\hline Orchards & 10 & Asparagus & 40 & Social life & 30 & Landscape & 10 & Moss & 20 \\
\hline “La Presa" (Dam) & 10 & Gastronomy & 60 & School noise & 10 & Bakery & 40 & Nature & 10 \\
\hline "La Reina" laundry fountain & 20 & Iberian products & 10 & & & Aromatic plants & 30 & Valverdeños personality & 90 \\
\hline Rain & 20 & Serrano ham (jamón) & 10 & & & Bodión river & 10 & Aromatics plants & 10 \\
\hline Light & 10 & Traditional pig slaughtering & 50 & & & Wet soil & 70 & Orchards products & 20 \\
\hline Najarrillo Mill & 10 & Bread & 40 & & & & & Sunset & 10 \\
\hline Nature & 30 & Bread and cakes & 30 & & & & & Social life & 10 \\
\hline Fog & 10 & Pestorejo (traditional dish) & 10 & & & & & & \\
\hline Children & 10 & Pringue colorá (traditional dish) & 10 & & & & & & \\
\hline Landscape & 70 & Salmorejo (traditional dish) & 10 & & & & & & \\
\hline Birds & 10 & Tomato & 10 & & & & & & \\
\hline Hermitage walk & 10 & & & & & & & & \\
\hline Sports court & 20 & & & & & & & & \\
\hline "El Pocito" drinking fountain & 20 & & & & & & & & \\
\hline Door church & 10 & & & & & & & & \\
\hline Sunset & 10 & & & & & & & & \\
\hline Bodión river & 30 & & & & & & & & \\
\hline "San Benito" Fest (patron saint) & 10 & & & & & & & & \\
\hline Mountains & 20 & & & & & & & & \\
\hline View from the Jaca & 10 & & & & & & & & \\
\hline Views of the town & 50 & & & & & & & & \\
\hline Views of the Montains from "El Pilar" & 10 & & & & & & & & \\
\hline
\end{tabular}


Table 5. Activity 2 results. Anomalous elements from the five senses. Number of times mentioned.

\begin{tabular}{|c|c|c|c|c|c|c|c|c|c|}
\hline SIGHT & No. & TASTE & No. & HEARING & No. & SMELL & No. & TOUCH & No. \\
\hline Non-integrated architecture & 10 & Tap water & 30 & Sharpener & 20 & Rubbish in containers & 40 & Holes in the pavement & 10 \\
\hline Church railing & 20 & Pork meat & 10 & & & Animal faeces & 60 & Asphalt & 10 \\
\hline Narrow paths & 10 & Missing indigenous species & 10 & Bells & 20 & Foul-smelling herbs & 10 & Bench seat & 10 \\
\hline Empty/deteriorated houses & 120 & New foods & 10 & Too quiet & 20 & Smoke & 10 & Increased summer heat & 20 \\
\hline Chapel enclosure & 10 & Artificial bread & 10 & Less nature & 10 & Smell animals in the street & 10 & Stoned streets & 20 \\
\hline Badly parked cars & 10 & Loss of gastronomy & 60 & Loud music & 40 & Firecrackers & 10 & Facades discordant paintings & 10 \\
\hline Stork's nest removal & 10 & Blood with tomato (typical dish) & 10 & Firecrakers & 10 & Slurry & 40 & Lack of expression of feelings & 10 \\
\hline Poor transport & 10 & Vegetables & 20 & Sunday noise & 10 & Dirt & 10 & Cold & 10 \\
\hline Rubble & 10 & & & Noise in the streets & 20 & Tobacco & 10 & The old TV club & 10 \\
\hline Foreign species & 10 & & & Noise parties & 20 & & & Animal faeces & 10 \\
\hline State of conservation of the church & 50 & & & Noise vehicle & 80 & & & Threshold & 10 \\
\hline State of conservation of the dam & 10 & & & Noise of "San Isidro" Fest & 100 & & & Loss of securities & 10 \\
\hline $\begin{array}{l}\text { State of conservation of "La Reina" } \\
\text { laundry fountain }\end{array}$ & 10 & & & Itinerant sale & 3 & & & Loss of people & 10 \\
\hline Facades & 20 & & & & & & & Big stone & 10 \\
\hline Discordant paintings on the facades & 30 & & & & & & & Personal relationships & 10 \\
\hline Unpainted facades & 30 & & & & & & & Tree felling & 10 \\
\hline Animal faeces & 10 & & & & & & & Fabrics & 10 \\
\hline Fewer people & 10 & & & & & & & & \\
\hline $\begin{array}{l}\text { "El Pocito" watering fountain } \\
\text { without water }\end{array}$ & 10 & & & & & & & & \\
\hline Few children & 20 & & & & & & & & \\
\hline Animal overexploitation & 10 & & & & & & & & \\
\hline Solitude & 10 & & & & & & & & \\
\hline
\end{tabular}




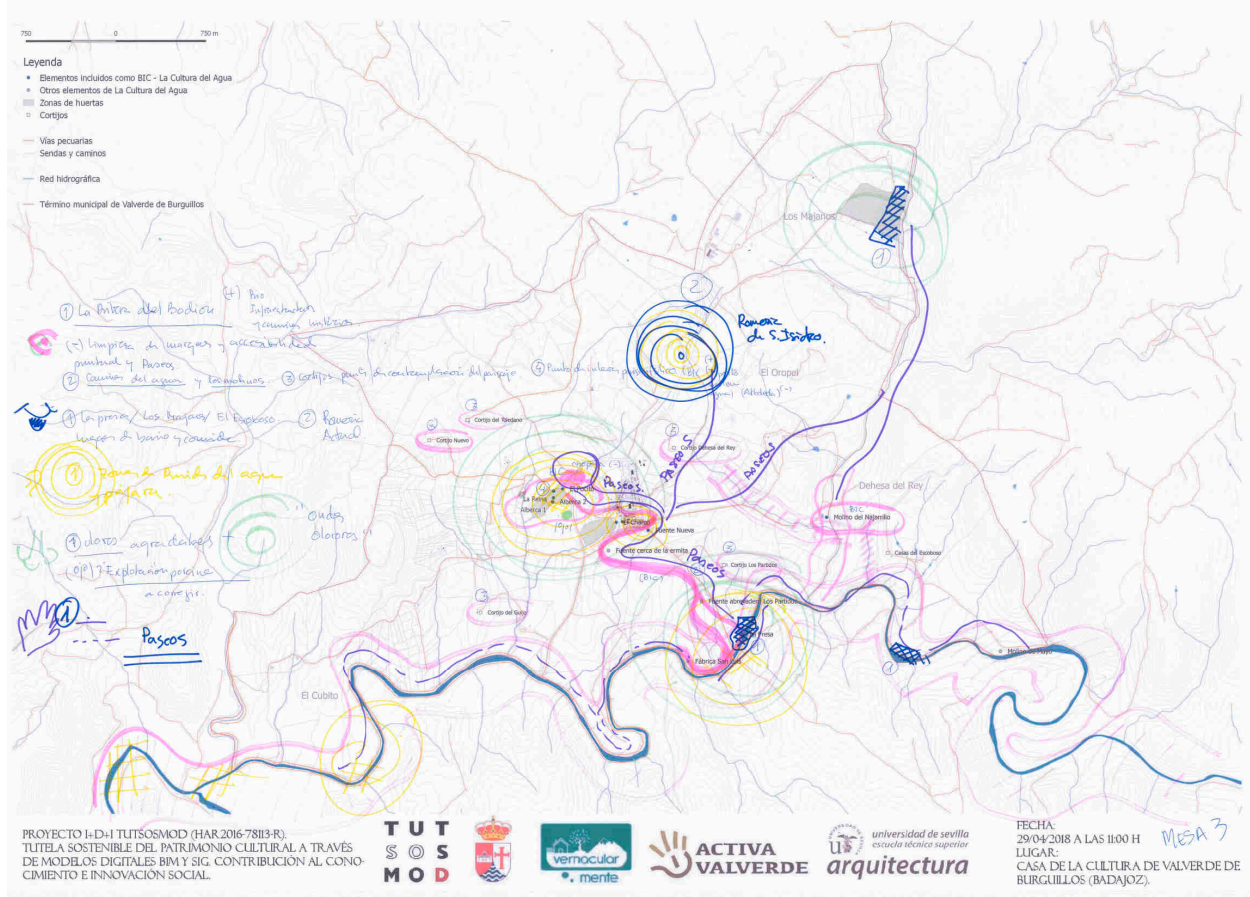

Figure 6. Map resulting from exercise 3, elements considered to feature historical heritage value. Authorship: citizens of Valverde.

\subsection{Phase 2: Reaching a Consensus. The Role of Cartographies}

The strategy of using collaborative mapping processes seeks to involve all the stakeholders who have generated information in the identification of heritage values and attributes, and, thus, construct a diagnosis that allows proposing rural development strategies based on citizen participation (Figure 7). Relational analysis is based on establishing the connection between elements and their environment. To this end, the existing connections between the elements of "La Cultura del Agua"; with the layers of information that comprise the Valverde de Burguillos territory defined by the specialists in the field and with the information provided by the general public have been assessed.

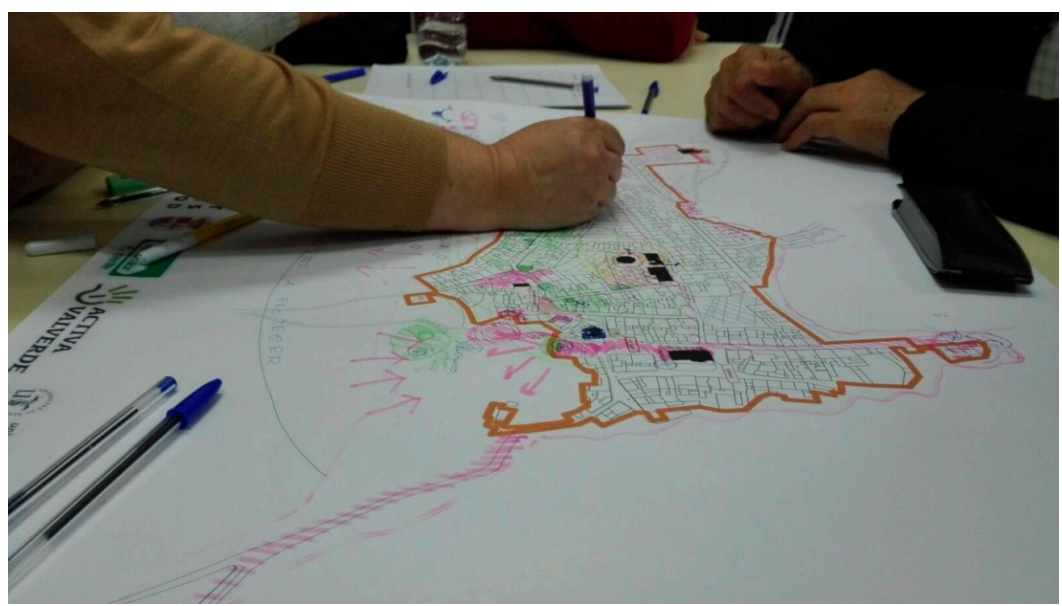

Figure 7. Citizens in the workshop working on collaborative cartographies. Authorship: TUTSOSMOD team.

Below, a selection of results of this analytical crossing of information is listed, while Figure 8 shows the overlapping of certain layers that are considered relevant: 
- Overlap with the cattle routes: streams, roads, trails, resting places, and royal herding tracks. There is no doubt that there is a close relationship between the elements, both those that are catalogued and those that are not, of "La Cultura del Agua" with the cattle trails that cross the urban centre of Valverde de Burguillos and make up the rural routes of the municipality. Almost all of the constructions are located on livestock pathways, except for "El Charco" and "El Pilar", which are located in the urban nucleus, which indicates that they are historical paths for ranchers and travellers to their lands or nearby municipalities (Figure 7). The livestock pathways are the following: "Colada del Camino del Ventoso" (where the "Fuente Nueva" is located); "Colada del Camino de Atalaya" (connects the urban nucleus of the municipality with the "Cañada Real de Burguillos"); "Cañada Real de Burguillos" (royal herding track) (links Valverde de Burguillos with Zafra, Burguillos del Cerro, and Jerez de los Caballeros and in it is the Najarrillo mill running to form the northeast border of the municipality of Valverde); rest of the Bodión River (borders and accompanies the Bodión River as it passes through the municipality of Valverde de Burguillos, linking the "San Luis" electrically powered flourmill, "La Presa" and the "Mayo" mill); "Colada de la Carretera" that connects the "Colada del Camino de Jerez" (the Jerez Laundry Path) with the Río Bodión at the level of "El Pocito" and reaches the "Colada del Camino de Atalaya" (Atalaya Laundry Path) at a point near the hermitage; the "Colada del Camino de Jerez" (the Jerez Laundry Path) (to the west of the urban centre, concentrates the largest number of elements included in "La Cultura del Agua" dossier).

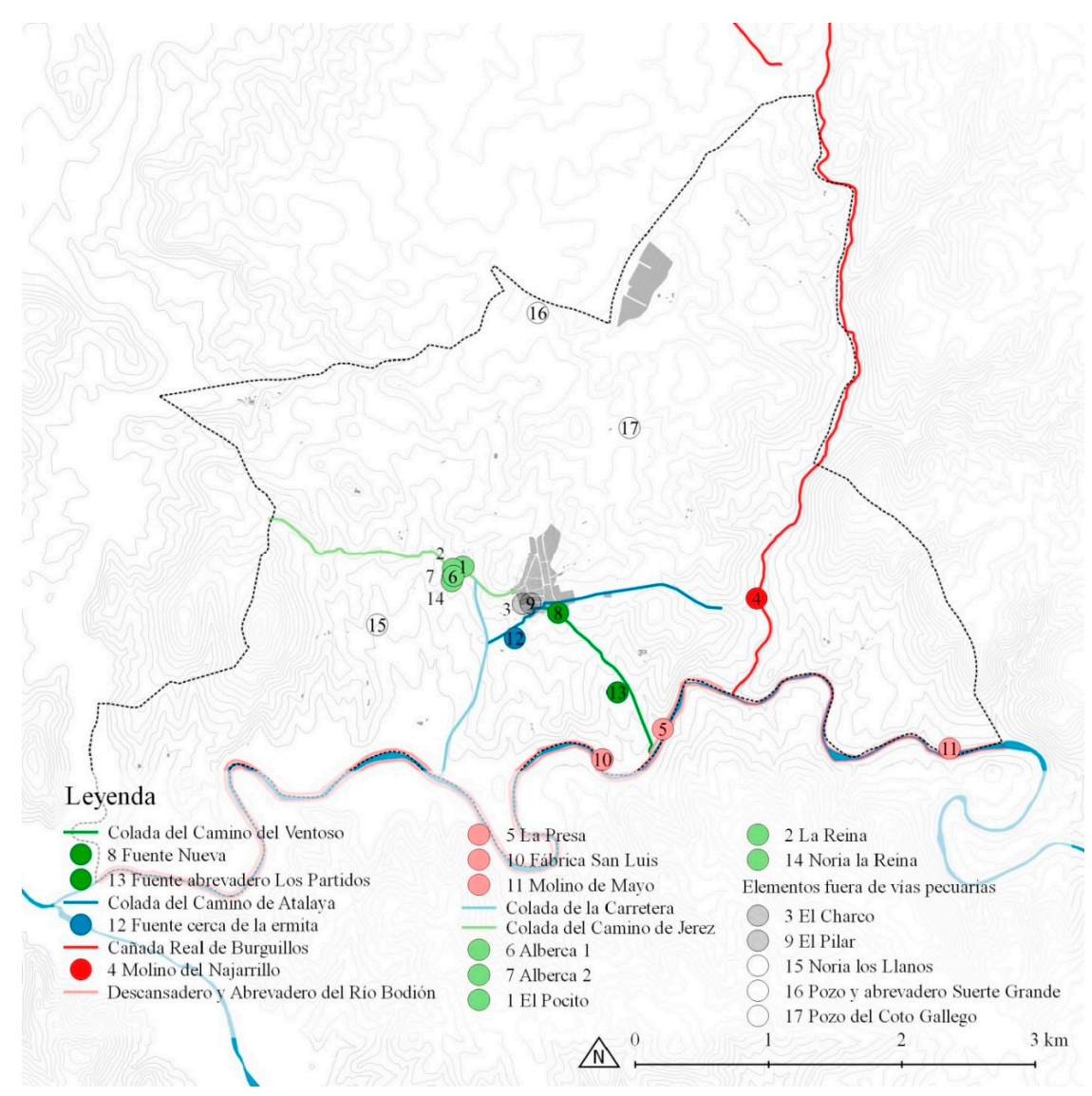

Figure 8. Example of a georeferenced map integrating elements of the territorial support provided by the Administration ("La Cultura del Agua") and the Technicians/University (livestock pathways). Prepared by the TUTSOSMOD working team and Irene Carnicero from the aforementioned cartographic bases.

- Hydrography and "La Cultura del Agua": While the relationship may be straightforward, it is of the utmost importance to analyse how these elements relate to it. If it seems plausible to partially 
justify the location of the different sources, cisterns, laundries, and other elements through the reading of the livestock pathways, the hydrographic reading of the territory responds to this question to a greater degree. A whole series of land elements underpins these fountains and pools, most of which, as in the case of "La Reina" and "El Pocito", are composed, in addition to water storage, of a system of ditches that distributes water to nearby orchards. In the case of sources located in the urban nucleus ("El Pilar" and "El Charco"), it is relevant that they rise in the vicinity of the source of a stream. Nowadays, these represent the urban boundary of Valverde de Burguillos and it is likely that this is due to the initial location of these elements, directly linked to the hydrography of the territory.

- Urban progression and "La Cultura del Agua": Since all the elements, except "Fuente Nueva" (1920), date from before 1900 and that the cadastral information dates the constructions from 1900, it is difficult to analyse urban evolution together with the progression of "La Cultura del Agua." However, the set of territorial elements that have been seen so far have considerably conditioned the location and development of the urban nucleus.

By overlapping all this information with the data provided by citizens, the elements of "La Cultura del Agua" are linked to landscape enclaves or places of collective identity. Likewise, the vernacular architecture identified by the University researchers is highlighted in the workshop as one of the elements of maximum identity. These are defined by citizens' proposals for improvement even in poorly preserved traditional elements, given its symbolic value, which has helped to outline the diagnosis (Figure 9).

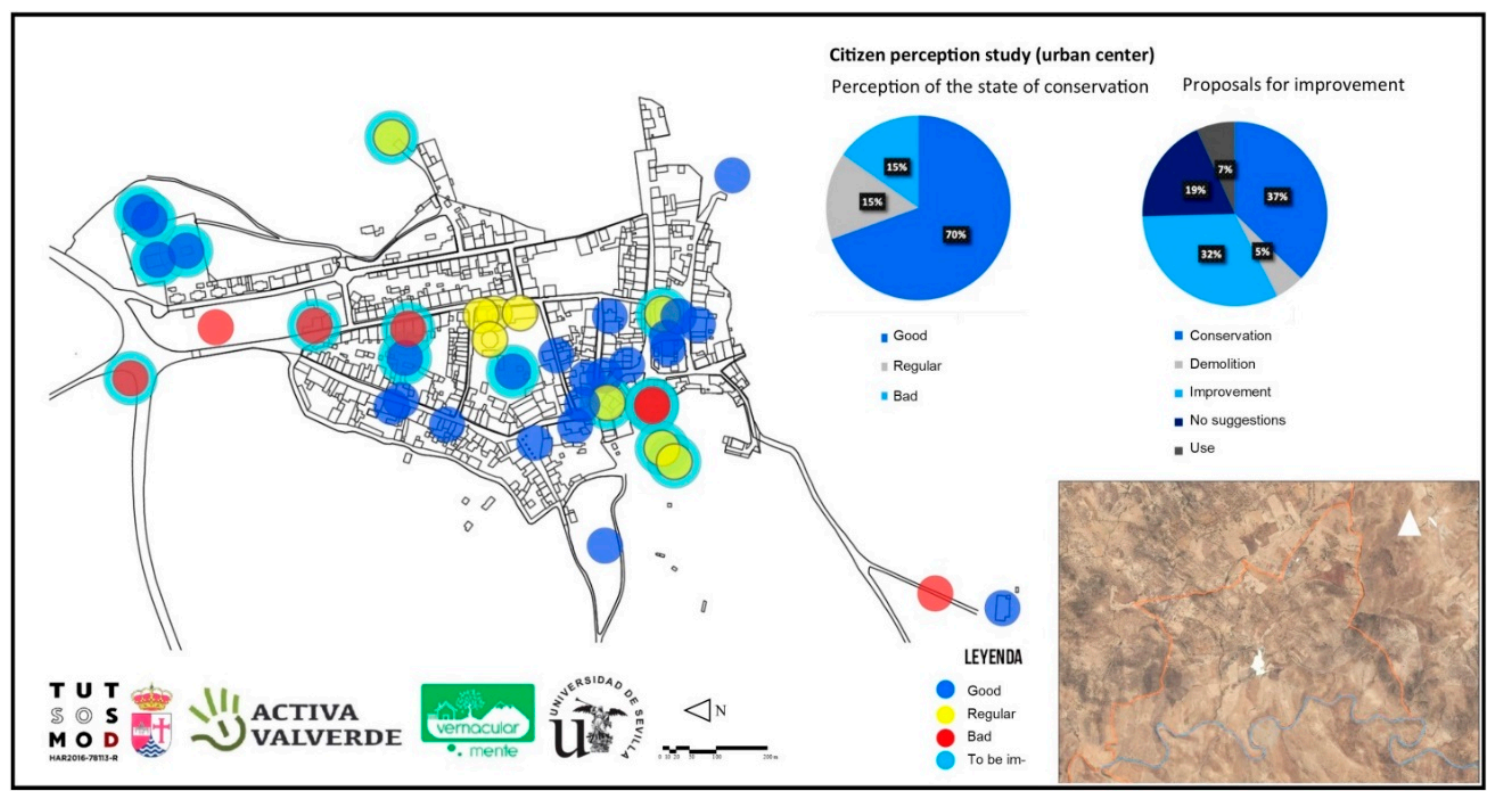

Figure 9. Planimetry created on vernacular architecture and its state of conservation. Prepared by the TUTSOMOD working team.

\subsection{Phase 3-Integration of Information in the Urban Development Framework}

The amount of information obtained from the stakeholders involved must be systematised so that its incorporation is useful and borne in mind within the urban development framework. To facilitate its integration, the resources have been grouped into material heritage, natural heritage, and intangible heritage; this grading does not imply a limitation on their use. It is more likely that it has been undertaken with a view to a practical identification of the resources requiring intervention. Material heritage refers to architectural elements and constructive singularities, although this group has considered the inclusion of vegetable gardens and livestock pathways, as they are tangible 
anthropized elements. The natural heritage has been arranged according to the resources that make up the agricultural landscape of Valverde. Finally, intangible heritage has sought to identify all those resources related to the knowledge and customs associated with a certain rural way of life that goes beyond picturesque or folkloric portrayals. The outcome of this systematisation has been the drawing up of a heritage map of the heritage resources of the municipality (Table 6) based on the information provided by the different stakeholders.

Table 6. Heritage map of the heritage resources of the municipality based on the information provided by the different stakeholders.

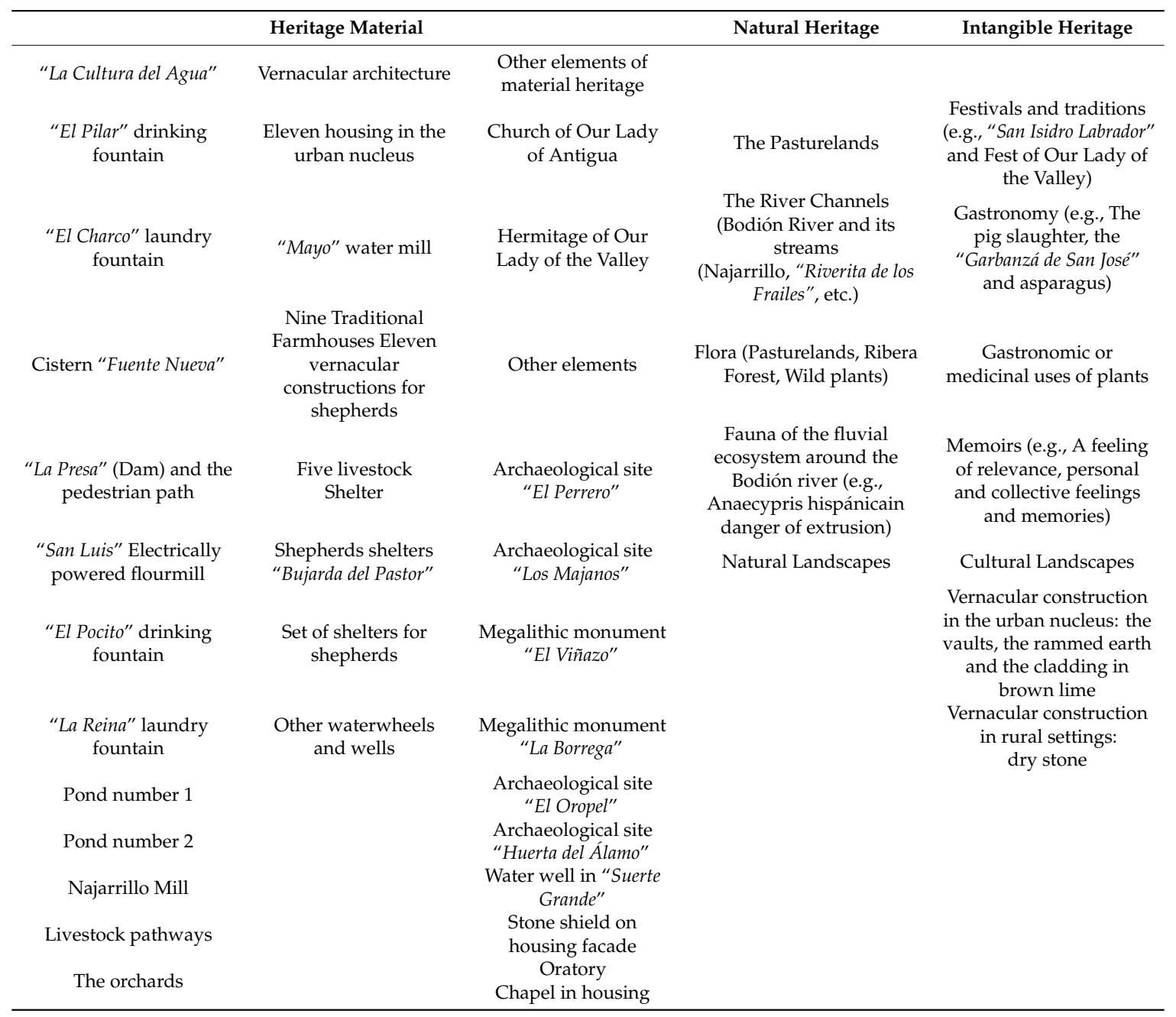

\section{Discussion}

Firstly, the BIC declaration proposal for the architectural elements of "La Cultura del Agua" entails historical and anthropological interest, since it represents the testimony of a territory brimming over with life. Through these elements, water ensured the self-sufficiency and irrigation of land for the inhabitants, pasture for the cattle that passed through them, fishing, plant species for construction or fuel and its driving force was used in manufacture, in this case, bread and electric light.

The architectural value of these constructions is also noteworthy. These are objective testimonies of the needs of users at a certain historical moment, which respond to constructive solutions, both material and technical, typical of the place. Knowledge learned and inherited from generation to generation is identified. Likewise, an urban value can be attributed to the different sources and cisterns, since they structure the urban fabric of the municipality and are located at relevant points for this development. For example, these act as a limit and articulating the transition of the urban nucleus with the space 
rural area of the periphery. In cases like "El Pilar", not only does it establish the boundary, it also creates a physical space for sociability in its surroundings, appearing as a large landscaped square that acts as a link with the Church of Our Lady of Antigua.

To these values, the landscape component must be similarly added. In tandem with these elements, a series of landscapes are devised, the result of environmental, socioeconomic, and cultural processes. These operate in continuous dynamism that support the knowledge, memoirs, and identities of the community. This cultural landscape must be perceived not only from the subjective visual or emotional component of its beauty, but from the value they possess from the cultural outlook, understanding the historical course of these landscapes from the evolution of ways of life and the anthropisation of the territory.

With regard to the symbolic value that these spaces have, the identity character that the different elements of collection, distribution, and accumulation of water have for Valverde de Burguillos and for Extremadura as a whole is undeniable. For the municipality, these elements have a transmittable knowledge regarding use, functionality, sociability, and neighbourhood coexistence (Figure 10). Indeed, this testimony is not solely historical, moreover, it endures over time when traditional irrigation systems are still maintained (for example, in the cases of "El Pilar" and "El Charco"), which has allowed and allows the transmission of agricultural knowledge to the new generations that otherwise would have been lost. In turn, the old "San Luis" electrically powered flourmill is a one-off hydraulic plant on a nationwide level. This provided the workers with employment and accommodation for their families in their own dependencies, according to certain local residents who spent their childhood there, meaning the road was travelled along on a daily basis to go to school, making the factory and its surroundings part of the collective imaginary. Finally, it is worth highlighting the toponymy of the area, a very significant aspect of the territories, which responds on numerous occasions to the elements of "La Cultura del Agua", such as the cases of "El Charco" street, "El Charco" little street, "El Pilar" street, or the "El Pocito" pathway.

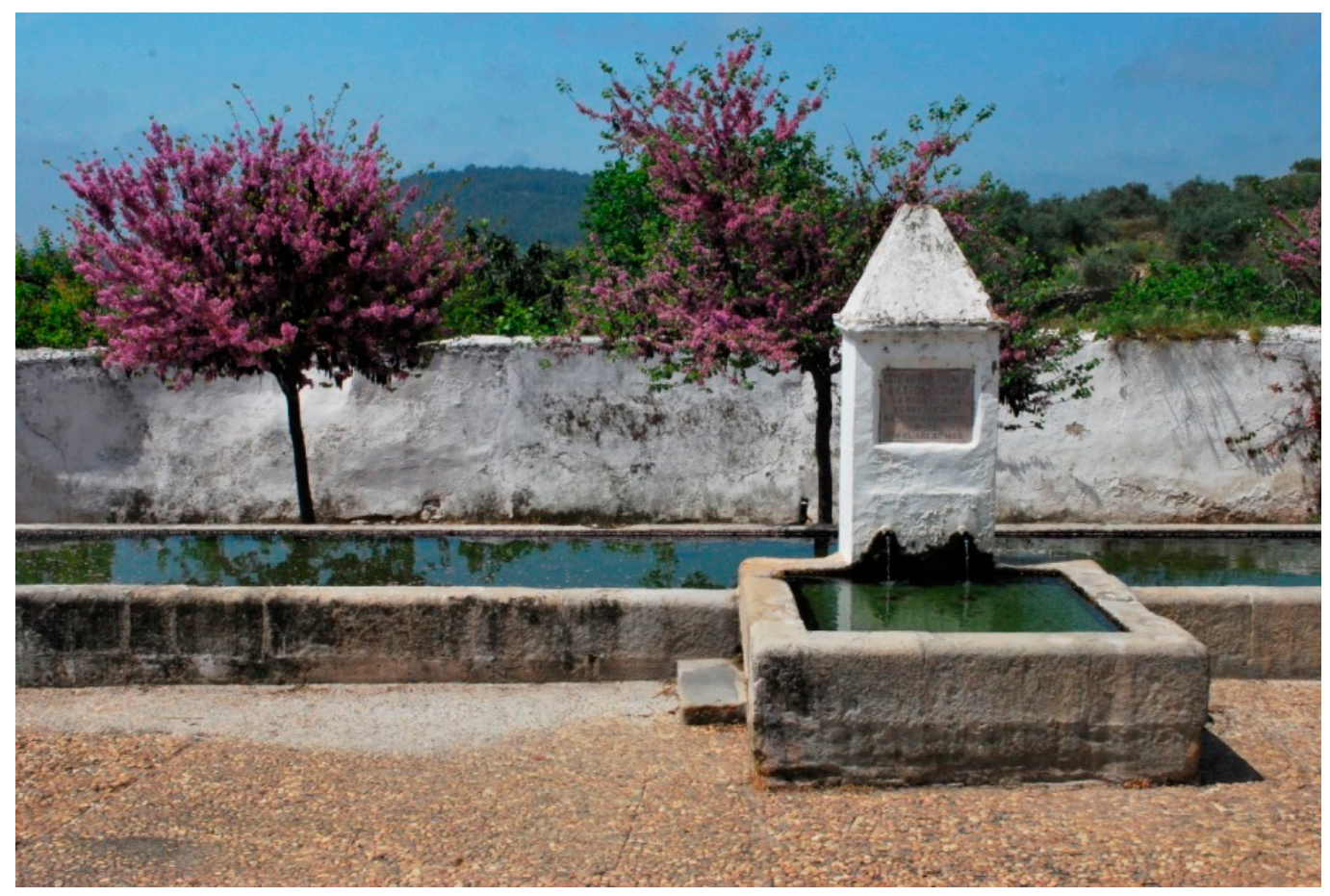

Figure 10. "El Pilar": element of "La Cultura del Agua" and focus of neighbourhood meetings in the urban landscape of Valverde de Burguillos. Authorship: Ángeles Martín de Prado.

Worthy of special mention is the close relationship that the elements of "La Cultura del Agua" have with the livestock pathways of Valverde de Burguillos, which in turn support the community's transit 
in local cultural expressions (pilgrimages, walks). Almost all of the buildings are placed on these livestock pathways. Given this circumstance, one concept cannot be understood without the other. In the case of the latter, "La Cultura del Agua" is an element that adds value, aside from its own intrinsic value. However, this culture is distributed, amongst other reasons, due to the previous layout of cattle trails, roads, and tracks that already formed the territory of Valverde de Burguillos (Figure 11).

When crossing with other data, such as the hydrographic network, it can be seen how each of the elements of "La Cultura del Agua", both those protected by the initiation of the file and those that are not, are emerging in direct line with the channels that form the municipality of Valverde de Burguillos, making it necessary to understand this dimension of the territory.

This territorial approximation also reaches a socioeconomic impact for the case study. The growing endowment of equipment, infrastructure, and territorial services (roads, highways, water supply, health, or educational services) has not slowed the demographic decline in smaller towns. However, the synergy between University, Administration, and citizenship is bearing its first fruits with the contribution to heritage knowledge and the boosting of existing resources. These academic works focus on determining the social, economic, and technical measures for the recovery of cultural heritage in keys of sustainability, transdisciplinarity, and citizen participation. Numerous academic studies carried out from 2015 onwards by the University of Seville propose Valverde de Burguillos as the driving force behind a network of small agro-ecological centres distributed in the Zafra-Río Bodión community. Similarly, from the workshops on vernacular initiatives with technicians and citizens, ideas were derived that have been addressed by the Administration. These include the future creation of the Bodión River Knowledge Centre, "a facility that centralises and boosts all aspects that directly affect the people and the territory and that condenses the enhancement of rural heritage in all its dimensions, capable of positioning itself in the region as a unique initiative for rural heritage and development" [76] (p. 68).

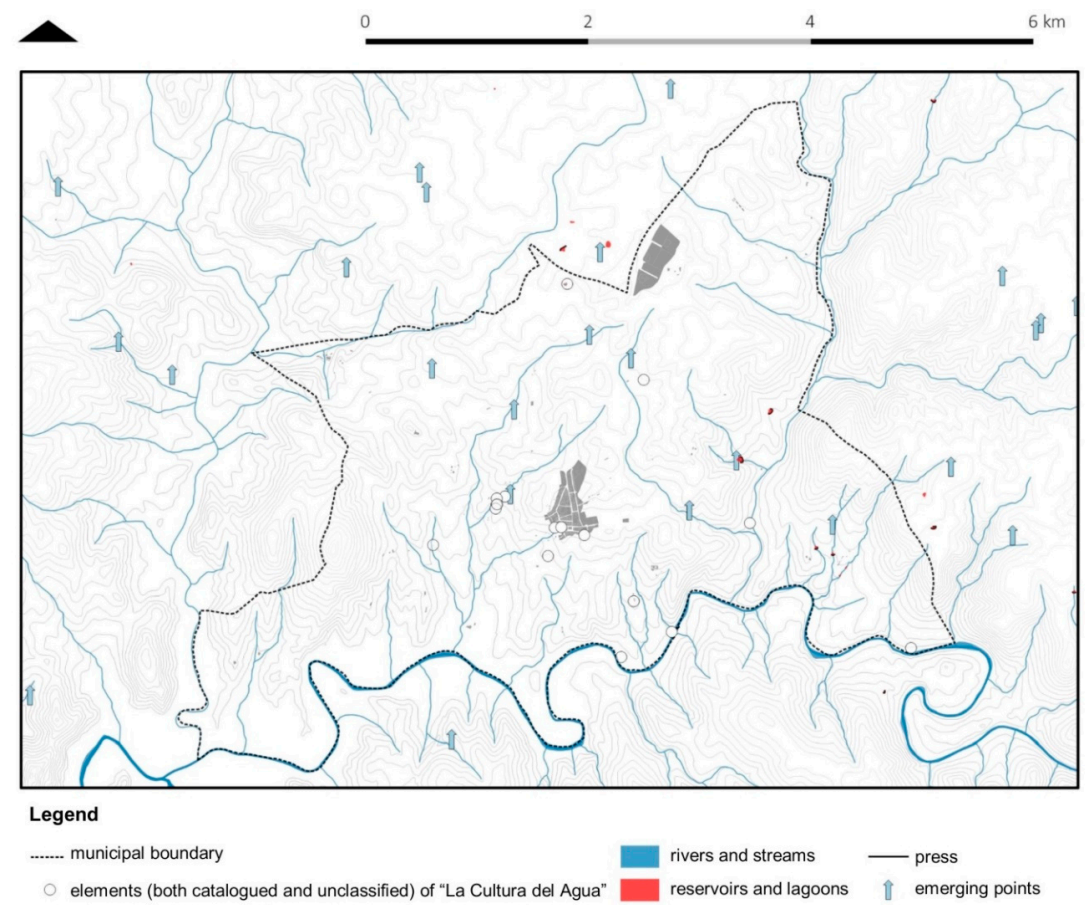

Figure 11. Hydrology and "La Cultura del Agua": rivers and streams, lagoons and reservoirs, dams, emergence points. Prepared by the TUTSOSMOD working team and Irene Carnicero from the aforementioned cartographic bases.

Finally, the social dimension of the urban fabric that the elements of "La Cultura del Agua" have had in the nucleus of Valverde de Burguillos is mainly down to two reasons. The first, the fact that 
they feed orchards and adjacent lands through a system of ditches that, alongside the volume of water they handle, represents an important agricultural area that has settled in its vicinity, in this case, to the southwest and, hence, the urban limit. The second reason, related to "El Pilar" exclusively, is its worthiness as a meeting point. This long-standing characteristic, together with the nearby location of the Church of Our Lady of Antigua (16th century), means that this place is a neuralgic point of sociability among the inhabitants. A system of small free spaces is created around these two elements: a square in front of "El Pilar", a free perimeter around the Church, and a small square to the south of it, a ground space that connects these two constructions and a small triangular free space that closes the nucleus at its northern limit. It is in this area of the town that bars and greengrocers are currently located. In the same way, and following the axis of activity, the playground and the Town Hall square are situated. Thus, Valverde de Burguillos has formed an axis of leisure, free spaces, and traffic around "El Pilar".

This approach to the heritage of Valverde de Burguillos from this integrative and holistic methodology provides a series of attributes that carry cultural values that must become the backbone of sustainable development strategies for said enclave (Figure 12). The Recommendation of the HUL resides in generating integrative methodologies whose viability and success is transposed into the variety of results submitted.

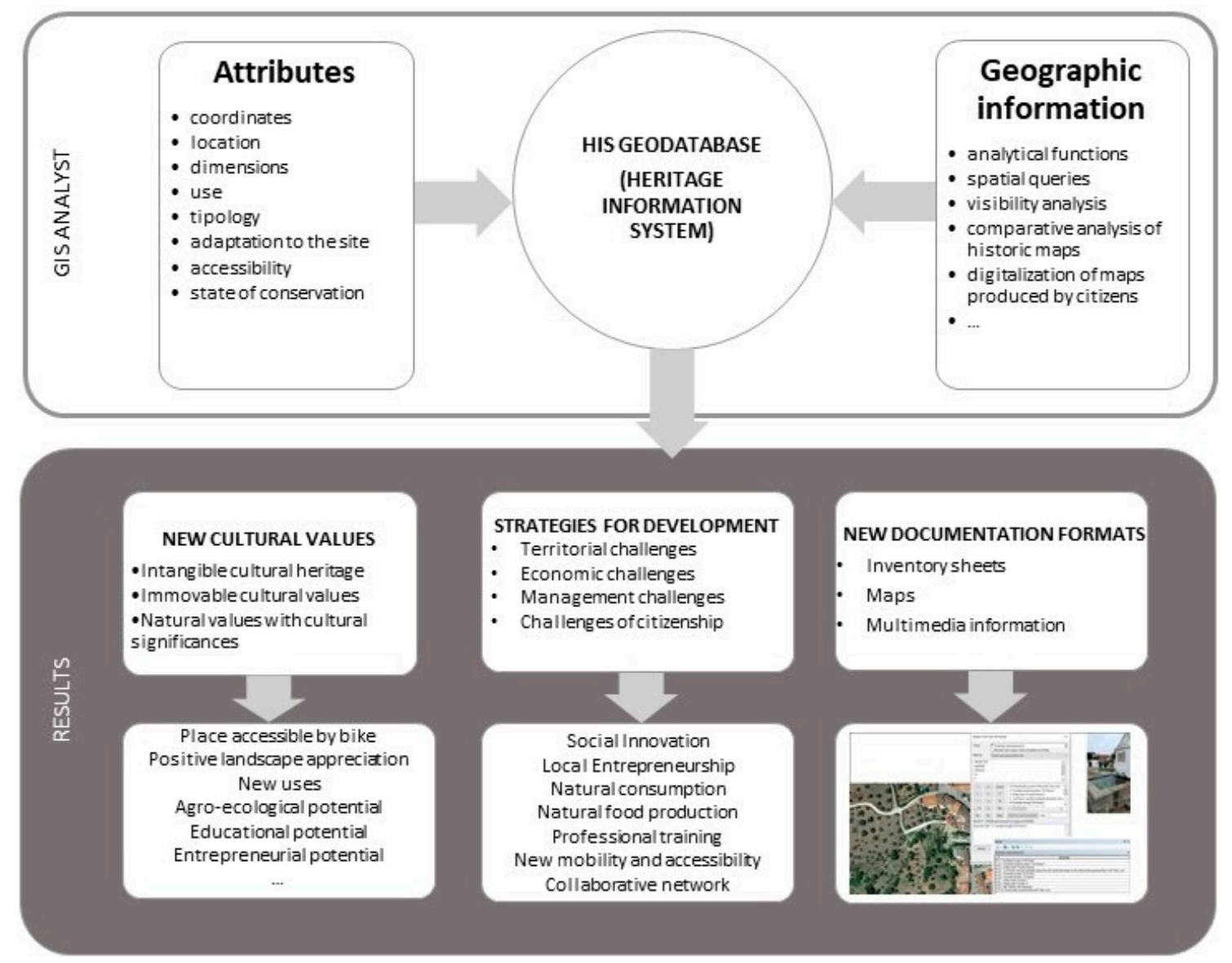

Figure 12. Attributes, functions, and values map. Prepared by the TUTSOSMOD working team.

\section{Conclusions}

This research has sought to initiate a study dynamic of cultural heritage that must be approached from the multidisciplinary dimension and by embracing new existing technologies. With the incorporation of all those disciplines that can collaborate in the study and enhancement of this heritage, new points of view and new data can be established on which to support its safeguarding. 
Until now, the study and the values associated with the Valverde built heritage have been established from "La Cultura del Agua" dossier and certain isolated elements taken into account in the General Plan. However, this multidisciplinary and inclusive methodology provides significant information hitherto overlooked in the sphere of heritage. This approach allows for innovative in-depth reflection regarding the population's perception and the sociocultural identity that their own architecture represents for the place. Tackling rural heritage from this perspective allows us to relate the information previously managed in a stagnant manner. As a result, this cultural heritage is placed in the territory or contrasted with other areas that, in turn, are also part of architecture, urban planning, social perception, and cultural identity. These areas linked to the territory go unnoticed since they are not usually rated in the same way that anthropic elements are valued. With this research, the need to capacitate urban governance on the part of the public sector administration is brought to the fore, as it falls to the latter to spearhead this shift in public management.

Conversely, the fact of having worked with the GIS tool and collaborative cartographies opens the door to new research and the continuation of this study. On this basis, data of a different nature should be added by the diverse stakeholders, and it should be treated as a dynamic tool, a driver of knowledge and experiences. This is the case of the inhabitants of the place, who can contribute lived experiences and historical information not presently gathered in writings, articles, or other bibliography. All this information generated and agreed upon is what can make up the proposal for a possible 'Strategic Plan' that integrates the management of the rural area into the general territorial development plan. In short, an inclusive sustainable development strategy built between all involved, and not limited to the perception of the administration.

Author Contributions: Conceptualization, J.R.-P. and V.D.-R.; methodology, J.R.-P. and V.D.-R.; investigation, J.R.-P. and V.D.-R.; picture editing, V.D.-R.; writing—review and editing, J.R.-P. All authors have read and agreed to the published version of the manuscript.

Funding: This research was funded by the Project HAR2016-78113-R of the 2016 RDI Project Call (Convocatoria 2016 de Proyectos de I+D+I), part of the State Programme for Research, Development and Innovation with Societal Ends (Programa Estatal de Investigación, Desarrollo e Innovación Orientada a los Retos de la Sociedad-Spain), a line of support in the research carried out in this study.

Acknowledgments: We would like to thank the students of the Higher Technical School of Architecture of the University of Seville who have participated during the research process and have helped with their final degree projects with part of the graphic material.

Conflicts of Interest: The authors declare no conflict of interest.

\section{References}

1. Pereira Roders, A.; Bandarin, F. (Eds.) Reshaping Urban Conservation. The Historic Urban Landscape Approach in Action; Springer Nature Singapore: Singapore, 2019. [CrossRef]

2. United Nations Human Settlements Programme (UN-Habitat). Urban Planning for City Leaders; United Nations Human Settlements Programme (UN-Habitat): Nairobi, Kenya, 2012, Available online: https://unhabita t.org/sites/default/files/download-manager-files/UNHabitatUPCL14-02624-Combine.pdf (accessed on 9 October 2020).

3. Sánchez-Mesa Martínez, L.J. Planning territorial policies against inner areas depopulation in Spain: Keys for sustainable management of cultural and environmental resources. Il Cap. Cult. 2019, 19, 53-81. [CrossRef]

4. Gallar Hernández, D.; Acosta Naranjo, R. La resignificación campesinista de la ruralidad: La Universidad Rural Paulo Freire. Rev. Dialectol. Tradic. Pop. 2014, 69, 285-304. (In Spanish) [CrossRef]

5. Cardoso, R.T.; Arango, M.A. Conocimiento local y culturas tradicionales como base para el desarrollo sostenible: El caso del uso y manejo de las dehesas de encina en el suroccidente peninsular. Etnicex: Rev. Estud. Etnográficos 2014, 6, 21-43. (In Spanish)

6. United Nations. Transforming Our World: The 2030 Agenda for Sustainable Development (A/RES/70/1); United Nations: New York, NY, USA, 2015, Available online: Ttps://www.un.org/en/development/desa/population/migration/ge neralassembly/docs/globalcompact/A_RES_70_1_E.pdf (accessed on 13 December 2019). 
7. UNESCO. Hangzhou Outcomes. International Conference ‘Culture for Sustainable Cities'; UNESCO: Hangzhou, China, 2015, Available online: http://www.unesco.org/new/fileadmin/MULTIMEDIA/HQ/CLT/pdf/SustCit _Hangzhou_Outcomes_EN.pdf (accessed on 10 October 2020).

8. United Nations. Implementation of the Outcomes of the United Nations Conferences on Human Settlements and on Housing and Sustainable Urban Development and Strengthening of the United Nations Human Settlements Programme (UN-Habitat); United Nations: New York, NY, USA, 2016, Available online: http://habitat3.org/w p-content/uploads/N1639668-English.pdf (accessed on 15 December 2019).

9. HABITAT III. Habitat III. Zero draft of the New Urban Agenda; Habitat III: Quito, Ecuador, 2016, Available online: https://www.worldurbancampaign.org/sites/default/files/Habitat\%20III\%20Zero\%20Draft\%20outc ome\%20document\%20(May\%202016)_0.pdf (accessed on 15 May 2019).

10. Council of Europe. Cultural Heritage in the 21st Century for Living Better Together. Towards a Common Strategy for Europe. Namur Declaration; Belgian Chairmanship CoE: Namur, Belgium, 2015, Available online: https://delegacionacreenecco.files.wordpress.com/2015/06/namur-declaration-en-final.pdf (accessed on 15 October 2020).

11. Pereira Roders, A.; Van Oers, R. Editorial: Bridging cultural heritage and sustainable development. J. Cult. Herit. Manag. Sustain. Dev. 2011, 1, 5-14. [CrossRef]

12. UNESCO. Culture Urban Future. Global Report on Culture for Sustainable Urban Development; Unesco: Paris, France, 2016, Available online: http://unesdoc.unesco.org/images/0024/002459/245999e.pdf (accessed on 20 April 2020).

13. Torres, J.C.; López, L.; Romo, C.; Soler, F. An Information System to Analize Cultural Heritage Information. In Progress in Cultural Heritage Preservation. EuroMed 2012. Lecture Notes in Computer Science; Ioannides, M., Fritsch, D., Leissner, J., Davies, R., Remondino, F., Caffo, R., Eds.; Springer: Berlin/Heidelberg, Germany, 2012; Volume 7616, pp. 809-816. [CrossRef]

14. Pinto Puerto, F.S. La tutela sostenible del patrimonio cultural a través de modelos digitales BIM y SIG como contribución al conocimiento e innovación social. PH Boletín Inst. Andaluz Patrim. Histórico 2009, 93, 27-29. (In Spanish) [CrossRef]

15. Domínguez-Ruiz, V.; Rey-Pérez, J.; Rivero-Lamela, G. Contribution to the Knowledge of Cultural Heritage via a Heritage Information System (HIS). The Case of 'La Cultura del Agua' in Valverde de Burguillos, Badajoz (Spain). Sustainability 2020, 12, 1141. [CrossRef]

16. Silva Pérez, R.; Fernández Salinas, V. El nuevo paradigma del patrimonio y su consideración con los paisajes: Conceptos, métodos y prospectivas. Doc. d'Anàlisi Geogràfica 2017, 63, 129-151. (In Spanish) [CrossRef]

17. Gullino, P.; Loris Beccaro, G.; Larcher, F. Assessing and Monitoring the Sustainability in Rural World Heritage Sites. Sustainability 2015, 7, 14186-14210. [CrossRef]

18. Tillería, J. La arquitectura sin arquitectos, algunas reflexiones sobre arquitectura vernácula. AUS [Arquitectura] Urbanismo/Sustentabilidad] 2017, 8, 12-15. (In Spanish) [CrossRef]

19. Rudofsky, B. Architecture Without Architects: A Short Introduction to Non-Pedigreed Architecture; Museum of Modern Art: New York, NY, USA, 1964.

20. Carrión Gútiez, A. Planes Nacionales de Patrimonio Cultural; Secretaría General Técnica, Subdirección General de Documentación y Publicaciones, Ministerio de Educación, Cultura y Deporte: Madrid, Spain, 2015. Available online: https://sede.educacion.gob.es/publiventa/descarga.action?f_codigo_agc=15101C (accessed on 12 July 2020). (In Spanish)

21. Maldonado Ramos, L.; Vela Cossío, F. Arquitectura popular en el Valle del Tiétar. Narria Estud. Artes Costumbres Pop. 1996, 75, 1-7. Available online: https://repositorio.uam.es/bitstream/handle/10486/8520/458 04_1.pdf?sequence=1 (accessed on 25 June 2020). (In Spanish)

22. Carrera, G. La arquitectura vernácula de la Andalucía rural. Un análisis comparado de dos inventarios. $A R A$. Tierra Sur. Patrim. Cult. Desarro. Rural Andalucía 2004, 15, 24-29. Available online: http://www.revistatierras ur.com/revistas/articulos/24-29TS15arquitecturavernacula.pdf (accessed on 15 September 2020). (In Spanish)

23. ICOMOS. Charter on the Built Vernacular Heritage (1999); ICOMOS: Roma Norte, Mexico, 1999, Available online: https://www.icomos.org/images/DOCUMENTS/Charters/vernacular_e.pdf (accessed on 30 August 2020).

24. Woods, M. Performing rurality and practising rural geography. Prog. Hum. Geogr. 2010, 34, 835-846. [CrossRef] 
25. OECD. Edinburgh Policy Statement on Enhancing Rural Innovation. In Proceedings of the 11th OECD Rural Development Conference, Edinburgh, UK, 9-12 April 2018, Available online: https://www.oecd.org/regional/ 11th-rural-development-conference.htm (accessed on 10 October 2020).

26. OECD. Delivering Rural Well-Being. In Proceedings of the 12th OECD Rural Development Conference, Seoul, Korea, 24-26 September 2019, Available online: https://www.oecd.org/rural/rural-development-conference/ (accessed on 10 October 2020).

27. Matero, F. Ethics and policy in conservation. Conser. Perspect. GCI Newsl. 2000, 15, 1. Available online: https://www.getty.edu/conservation/publications_resources/newsletters/15_1/feature1_2.html (accessed on 10 September 2020).

28. Roders, A.P. How can urbanization be sustainable? A reflection on the role of city resources in global sustainable development. BDC. Boll. Del Cent. Calza Bini 2013, 13, 79-90. [CrossRef]

29. O'Connor, J. Panel discussion on the contribution of creativity to sustainable development. In Proceedings of the UNESCO Hangzhou International Congress, Culture: Key to Sustainable Development, Hangzhou, China, 15-17 May 2013.

30. Gómez, J.I.L. Dos experiencias de recuperación integral del patrimonio arquitectónico: La Catedral de Santa María de Vitoria y el Valle Salado de Salinas de Añana. Berceo 2006, 151, 133-143. (In Spanish)

31. UNESCO. Preliminary Report on the Draft Recommendation on the Historic Urban Landscape; UNESCO: París, France, 2010, Available online: https://unesdoc.unesco.org/ark:/48223/pf0000189099. (accessed on 12 October 2020).

32. Portugués, I.M. Mértola Vila Museu. Modelo rural de difusión del Patrimonio Cultural. In Cuadernos de Investigación Urbanística (Ci[ur]), 1st ed.; Instituto Juan de Herrera, Ed.; Universidad Politecnica de Madrid-University Library: Madrid, Spain, 2018; Volume 117, pp. 1-80. (In Spanish) [CrossRef]

33. Evans, G. Measure for measure: Evaluating the evidence of culture's contribution to regeneration. Urban Stud. 2005, 42, 959-983. [CrossRef]

34. Nijkamp, P.; Riganti, P. Assessing cultural heritage benefits for urban sustainable development. Int. J. Serv. Technol. Manag. 2008, 10, 29-38. [CrossRef]

35. Verdini, G.; Frassoldati, F.; Nolf, C. Reframing China's heritage conservation discourse. Learning by testing civic engagement tools in a historic rural village. Int. J. Herit. Stud. 2017, 23, 317-334. [CrossRef]

36. Rey-Pérez, J.; Siguencia Ávila, M.E. Historic urban landscape: An approach for sustainable management in Cuenca (Ecuador). J. Cult. Herit. Manag. Sustain. Dev. 2017, 7, 308-327. [CrossRef]

37. Buckley, K.; Cooke, S.; Fayad, S. Using the Historic Urban Landscape to re-imagine Ballarat. The local context. In Urban Heritage, Development and Sustainability. International Frameworks, National and Local Governance; Labadi, S., Logan, W., Eds.; Routledge, Taylor and Francis Group: London, UK; New York, NY, USA, 2016; pp. 93-113.

38. Tweed, C.; Sutherland, M. Built cultural heritage and sustainable urban development. Landsc. Urban Plan. 2007, 83, 62-69. [CrossRef]

39. Scheffler, N.; Kulikauskas, P.; Barreiro, F. Managing urban identities: Aim or tool of urban regeneration? Urbact Trib. 2009,9-13. Available online: https://www.academia.edu/5882659/Managing_Urban_Identities_01. (accessed on 17 November 2020).

40. Chías, P.; Abad, T. GIS tools for comparing historical and contemporary landscapes through local map series. e-Perimetron 2009, 4, 61-72.

41. Sharma, R.S.; Samuel, E.M.; Ng, E.W. Beyond the digital divide: Policy analysis for knowledge societies. J. Knowl. Manag. 2009, 13, 373-386. [CrossRef]

42. Statuto, D.; Cillis, G.; Picuno, P. GIS-based Analysis of Temporal Evolution of Rural Landscape: A Case Study in Southern Italy. Nat. Resour. Res. 2019, 28, 61-75. [CrossRef]

43. INE-Instituto Nacional de Estadística. Available online: https://www.ine.es/ (accessed on 1 January 2019).

44. Fundación BBVA. La población de Badajoz; Fundación BBVA: Madrid, Spain, 2007. (In Spanish)

45. Acosta-Naranjo, R.; Domínguez Jara, J.A.; Domínguez-Ruiz, V. Activa Valverde, un caso de vinculación de la sociedad civil y la Universidad contra la despoblación. Rev. PH Inst. Andaluz Patrim. Histórico 2019, 98, 210-221. (In Spanish) [CrossRef]

46. Gallardo, J.A. Apuntes Para la Historia de Valverde de Burguillos; Diputación de Badajoz: Badajoz, Spain, 2014. 
47. Herrera Rodríguez, K.G. Edaphoclimatic Potential of Valverde de Burguillos for Ecological Agriculture and the Acclimatisation of Some Crops Typically Found in the Latin American Diet. Master's Thesis, Universidad Internacional de Andalucía, Seville, Spain, 24 September 2019.

48. Centro de Descargas. Sistema de Información Territorial de Extremadura SITEX. Available online: http: //sitex.gobex.es/SITEX/centrodescargas (accessed on 2 August 2020). (In Spanish).

49. Carnicero Valero, I. "La Cultura del Agua" in the Territorial Enclave of Valverde de Burguillos. Characterization of the Ethnographic Heritage through Geographic Information Systems. Bachelor's Thesis, Universidad de Sevilla, Sevilla, Spain, 2018. Available online: https://personal.us.es/racosta/Articulos /12.TFG-L_ICV-entregado.pdf (accessed on 25 January 2020).

50. Consejería de Cultura e Igualdad de la Junta de Extremadura. Resolución de 22 de Marzo de 2019, de la Consejería de Cultura e Igualdad, por la que se Incoa Nuevo Expediente, para la Declaración de Bien de Interés Cultural a Favor de 'La Cultura del Agua' en Valverde de Burguillos (Badajoz). Boletín Oficial del Estado, Núm. 150 de 24 de Junio de 2019. Referencia BOE-A-2019-9510. 2019, pp. 67207-67222. Available online: https://www.boe.es/diario_boe/txt.php?id=BOE-A-2019-9510 (accessed on 14 October 2020). (In Spanish)

51. España, Ley 2/1999, de 29 de marzo, de Patrimonio Histórico y Cultural de Extremadura. Boletín Oficial del Estado, núm. 139, de 11 de junio de 1999. Referencia BOE-A-1999-13022. 1999. Available online: https: //www.boe.es/buscar/pdf/1999/BOE-A-1999-13022-consolidado.pdf (accessed on 2 March 2019). (In Spanish)

52. UNESCO. Recommendation on the Historic Urban Landscape, Including a Glossary of Definitions. 2011. Available online: http://portal.unesco.org/en/ev.php-URL_ID=48857\&URL_DO=DO_TOPIC\&URL_SECTI ON=201.html (accessed on 23 April 2019).

53. Río Bodión Community. Office of Urban Management, Housing, Architecture and Territory. Municipal Masterplan Valverde de Burguillos “Documento de Avance Memoria Informativa". Available online: http://extremambiente.juntaex.es/files/Memoria\%20Informativa\%20PGM\%20Valverde\%20de\%2 OBurguillos.pdf (accessed on 2 May 2020).

54. Consejería de Medio Ambiente y Rural, Políticas Agrarias y Territorio. Available online: http://extremambiente .juntaex.es/index.php?option=com_content\&view=article\&id=1026\&Itemid=171 (accessed on 10 May 2018). (In Spanish)

55. Sistema Geográfico Nacional de Parcelas Agrícolas SIGPAC. Available online: http://sigpac.mapama.gob.es/f ega/visor; https://www1.sedecatastro.gob.es/ (accessed on 23 April 2018). (In Spanish)

56. Sistema de Información Geográfico Agrario SIGA. Available online: https://www.mapa.gob.es/es/agricultura /temas/sistema-de-informacion-geografica-de-datos-agrarios/ (accessed on 13 December 2019). (In Spanish)

57. Castellanos Mendoza, M. Vernacular Housing Architecture in Valverde de Burguillos (Badajoz). Contribution to the Knowledge of Its Heritage Values. Bachelor's Thesis, Universidad de Sevilla, Sevilla, Spain, 2018. Available online: https://personal.us.es/racosta/Articulos/11.Prueba.NOTFG_Mo\%CC\%81nicaCastellanosMe ndoza.pdf (accessed on 15 September 2020).

58. WMS Ortofoto PNOA del Instituto Geográfico Nacional. Available online: http://www.juntadeandalucia.es/ medioambiente/site/rediam/menuitem.04dc44281e5d53cf8ca78ca731525ea0/?vgnextoid=2d0c5997c8de541 0VgnVCM2000000624e50aRCRD\&vgnextchannel=867122ad8470f210VgnVCM1000001325e50aRCRD\&v gnextfmt=rediam\&lr=lang_en (accessed on 30 June 2019). (In Spanish)

59. Centro de Información Cartográfica y Territorial de Extremadura (CICTEX). Available online: http://sitex.go bex.es/SITEX/centrodescargas/viewsubcategoria/43 (accessed on 30 June 2019). (In Spanish)

60. Pérez Morillo, J.M. Diagnosis of productive alternatives linked to organic farming and processing of its products into Valverde de Burguillos (Badajoz). Master's Thesis, Universidad Pablo de Olavide, Sevilla, Spain, 2018. Available online: https://personal.us.es/racosta/Articulos/14.\%20TFM\%20JOSE\%20MAR\%C3\%8 DA\%20P\%C3\%89REZ\%20MORILLO-2-134.pdf (accessed on 25 January 2020).

61. Martínez Barrena, J.A. Ecological Use of Wild Plants in Valverde de Burguillos (Badajoz). Master's Thesis, Universidad Pablo de Olavide and Universidad Internacional de Andalucía, 2019. Available online: https://personal.us.es/racosta/Articulos/5.\%20TFM\%20_JA_MZ_Barrena.pdf (accessed on 25 January 2020).

62. Bermúdez Vázquez, V. Asparagus Harvesting in the Face of Depopulation in Valverde de Burguillos (Badajoz). Master's Thesis, Universidad de Sevilla,, Seville, Spain, 2018. Available online: https://personal.us.es/racosta /Articulos/3.\%20TFM_ESPA\%CC\%81RRAGOS\%20VIRGINIA\%20BERMUDEZ\%20VAZQUEZ.pdf (accessed on 25 January 2020). 
63. Blasco Martín, E. Current Situation and Potential for Agro-Ecological Development of the Bodión River and its Surrounding Ecosystems for Valverde de Burguillos (Badajoz). Master's Thesis, Universidad Internacional de Andalucía,, Sevilla, Spain, 2017. Available online: https://personal.us.es/racosta/Articulos/15.\%20NO.\%2 OTFM_VAlverde_ElenaBlasco.pdf (accessed on 25 January 2020).

64. Guillén Camisón, P. Approach to Digital Knowledge for the Dissemination of Architectural Heritage as A Measure to Combat Depopulation. Case Study: Valverde de Burguillos (Badajoz). Master's Thesis, Universidad de Sevilla, Seville, Spain, 2019. Available online: https://personal.us.es/racosta/Articulos/Patrici a\%20Guillen_Plataforma_final.pdf (accessed on 30 June 2019).

65. Rodríguez Maguillo, J. A Collaborative Platform to Enhance the Vernacular Heritage in Rural Settings. Bachelor's Thesis, Universidad de Sevilla, Sevilla, Spain, 2018. Available online: https://personal.us.es/racos ta/Articulos/13.MemoriaTFG-Javier.pdf (accessed on 5 July 2020).

66. Sesma Álvarez, T. Application of New Technological Advances to Built Rural Heritage. Analysis of the Current State and Proposal for the Use of the Najarrillo Mill, Valverde de Burguillos, Badajoz. Master's Thesis, Universidad de Sevilla, Sevilla, Spain, 2017.

67. Carrascosa Goméz, I. Constructive Characterisation of Vernacular Buildings of a Vernacular Nature in Valverde de Burguillos: Cataloguing, Analysis, Recommendations for Maintenance and Repairs in Raw Earth Walls and Masonry. Bachelor's Thesis, Universidad de Sevilla, Sevilla, Spain, 2018. Available online: https://idus.us.es/handle/11441/79494 (accessed on 2 October 2020).

68. Arévalo Ortíz, C. Identification and Recovery of the Food Heritage Related to the Sensory Landscape of the Inhabitants of Valverde de Burguillos and Analysis of the Potential of the Enhancement of a Product Related to the Territory. Master's Thesis, Universidad de Sevilla,, Seville, Spain, 2018. Available online: https://personal.us.es/racosta/Articulos/2.TFM_CECILIA_culturaalimentaria.pdf (accessed on 10 August 2020).

69. Zúñiga Sepúlveda, D. The Audiovisual Register as an Instrument for the Integration and Socialisation of Cultural Heritage in Valverde de Burguillos. Master's Thesis, Universidad de Sevilla, Seville, Spain, 2018. Available online: https://personal.us.es/racosta/Articulos/4.\%20TFM_DANIELA.pdf (accessed on 30 August 2019).

70. I Taller de Iniciativas Vernáculas. Patrimonio y Sostenibilidad Para Una Nueva Ruralidad; Domínguez-Ruiz, V., Rivero-Lamela, G., Eds.; III Plan Propio de Docencia de la Universidad de Sevilla: Sevilla, Spain, 2018. (In Spanish)

71. Rey-Pérez, J.; Domínguez-Ruiz, V. II Taller de Iniciativas Vernáculas en Valverde de Burguillos. Crónica del Bodión 2019, 1, 18. (In Spanish)

72. Calderón Torres, C.M. Arquitectura vernácula de Extremadura I: Diseño de un inventario. Oficina de Patrimonio Etnológico. Dirección General de Patrimonio Cultural. Junta de Extremadura. Consejería de Cultura y Turismo: Madrid, Spain, 2011. Available online: https://www.scribd.com/document/451742425/ARQUITECTURA-VERNA CULA-DE-EXTREMADURA-I-Diseno-de-un-Inventario-OFICINA-DE-PATRIMONIO-ETNOLOGICO-1-pdf (accessed on 2 September 2020). (In Spanish)

73. Díaz García, E. El Inventario de arquitectura vernácula en Extremadura supera los 6000 registros. Rev. $P H$ 2009, 72, 8-9. (In Spanish) [CrossRef]

74. Rey-Pérez, J.; Tenze, A. The citizen participation in the Management of Urban Heritage of the city of Cuenca (Ecuador). Estoa, Rev. la Fac. Arquit. y Urban. la Univ. Cuenca 2018, 7, 129-141. [CrossRef]

75. Medeiros, E.; van der Zwet, A. Sustainable and Integrated urban Planning and Governance in Metropolitan and Medium-Sized Cities. Sustainability 2020, 12, 5976. [CrossRef]

76. STOA. Strategies for Enhancing the Rural Heritage of Valverde de Burguillos as a Driving Force for Rural Development. A STOA Project for the Town Council of Valverde de Burguillos; Rural Development Programme of Extremadura 2014-2020; STOA: Badajoz, Spain, 2020.

Publisher's Note: MDPI stays neutral with regard to jurisdictional claims in published maps and institutional affiliations. 